DOI: 10.35757/RPN.2015.23.02

Marcin Markowski

\title{
SZATA GRAFICZNA PIENIĘDZY PAPIEROWYCH EMITOWANYCH NA TERENACH OKUPOWANYCH PRZEZ WOJSKA NIEMIECKIE PODCZAS PIERWSZEJ WOJNY ŚWIATOWEJ
}

W sierpniu 1914 roku wybuchła pierwsza wojna światowa. Pierwsze miesiące wojny przyniosły zmienne szczęście stronom walczącym na froncie wschodnim. Po początkowych sukcesach wojsk państw centralnych doszło do rosyjskiej kontrofensywy, w wyniku której na północy udało się zatrzymać pas przygraniczny, tracąc prawie całe Prusy Wschodnie. Natomiast na południu wojska rosyjskie i ich sprzymierzeńcy zajęli niemal całą Galicję, Bukowinę, Ruś Zakarpacką i część Transylwanii ${ }^{1}$. Ofensywa wojsk państw centralnych została podjęta 2 maja 1915 roku. Dwa dni później pod Gorlicami został przełamały front rosyjski. W wyniku udanej ofensywy w sierpniu całe Królestwo Polskie znalazło się pod okupacją wojsk austro-węgierskich i niemieckich. Sukcesy militarne armii państw centralnych na tym froncie przesunęły działania wojenne daleko na wschód. Od końca października 1915 roku front ustalił się na linii od Zatoki Ryskiej na północy przez Dźwińsk, Pińsk do Tarnopola na południu². Wówczas zostały zajęte graniczące z Prusami Wschodnimi ziemie wchodzące w skład daw-

1 B. Paszkiewicz, "Ostrubel" i "ostmarka”. O pieniadzu okupacji niemieckiej na Litwie, „Biuletyn Numizmatyczny” 1982, nr 7, s. 130.

2 J. Pajewski, Historia powszechna 1871-1918, wyd. 8, Warszawa 1999, s. 355; M. Markowski, Od marki polskiej do złotego, „Lubelskie Wiadomości Numizmatyczne” 2011, nr 17, s. 99. 
nego Wielkiego Księstwa Litewskiego z Lipawa, Grodnem, Kownem, Wilnem i Nowogródkiem. Na okupowanych terenach nazwanych przez władze niemieckie Gebiet des Oberbefehlshabers Ost (Obszar Głównodowodzącego Wschodu), w skrócie „Ober-Ost”, została utworzona administracja wojskowa $\mathrm{z}$ siedzibą w Kownie. Zajęte przez wojska niemieckie terytorium zostało podzielone na trzy obszary podlegające odpowiednio administracji wojskowej: Kurlandii, Litwy i białostocko-grodzieńskiej. Na obszarze Ober-Ostu Rzesza Niemiecka wprowadziła do obiegu własne, okupacyjne środki płatnicze. W tym celu 17 kwietnia 1916 roku głównodowodzący Obszaru Wschodu feldmarszałek Paul von Hindenburg ${ }^{3}$ wydał rozporządzenie, na mocy którego Bank Wschodni Handlu i Rzemiosła w Poznaniu, a bezpośrednio jego Wschodnia Kasa Pożyczkowa (Darlehnskasse Ost) stała się instytucją emisyjną.

Darlehnskasse Ost wprowadziła do obiegu żelazne monety o nominałach: 1, 2 i 3 kopiejki, które zostały wybite w 1916 roku w mennicach w Berlinie i Hamburgu ${ }^{4}$. Do obiegu weszły również pieniądze papierowe, które nosiły miano „Wykazów kasy pożyczkowej”. W ich szacie graficznej została umieszczona klauzula prawna w czterech językach: niemieckim, litewskim, łotewskim i polskim ${ }^{5}$. Do obiegu wprowadzono siedem różnych nominałów opiewających na kopiejki i ruble. Wszystkie „wykazy” miały jednakową datę emisji - 17 kwietnia 1916 roku, która była datą wydanego przez Hindenburga rozporządzenia o emisji „wykazów".

3 Hindenburg pełnił tę funkcję od 1 października 1914 do 29 sierpnia 1916 roku. Jego następcą został feldmarszałek książę Leopold Bawarski. Siedzibą głównodowodzącego Obszaru Wschodu był pałac rosyjskiego komendanta twierdzy w Kownie. B. Paszkiewicz, op. cit., s. 131.

4 U dołu awersów monet wybitych w mennicy berlińskiej znajduje się litera "A". Natomiast na monetach wybitych w Hamburgu litera "J". W. Szaflik, Monety obiegowe niemieckich władz okupacyjnych. Dla terenów Wschodnich, w: J. Parchimowicz, Monety polskie od roku 1916, Szczecin 1996, s. 12.

5 Na początku 1917 roku w prasie wileńskiej i warszawskiej pojawiły się informacje, że na „wykazach” Wschodniej Kasy Pożyczkowej o nominałach 3, 10 i 25 ostrubli pojawi się również język białoruski. Informacje te zostały powtórzone w redagowanych przez krakowskiego numizmatyka Mariana Gumowskiego „Wiadomościach Numizmatyczno-Archeologicznych”. Język białoruski na banknotach, „Wiadomości Numizmatyczno-Archeologiczne" 1917, nr 4, s. 179. 
Do obiegu wprowadzono dwa banknoty opiewające na 20 i 50 kopiejek oraz pięć o wartościach nominalnych - 1, 3, 10, 25 i 100 rubli $^{6}$. $\mathrm{Na}$ pieniądzach papierowych o nominałach 50 kopiejek oraz 1 i 3 ruble występują różnice $\mathrm{w}$ długości klauzuli prawnej zapisanej w języku polskim ${ }^{7}$. Na nominale 50 kopiejek z umieszczoną na awersie dłuższą klauzulą prawną brak jest litery ",i" w polskiej nazwie waluty, zamiast „kopiejek” jest „kopejek”. Wprowadzone przez Niemców na tych terenach ruble przeszły do historii jako „ostruble” lub „ruble wschodnie". Wschodnia Kasa Pożyczkowa działała na zasadzie lombardu, emitując „wykazy”, które zastępowały ściąganą z rynku rosyjską walutę, przejmowane carskie papiery wartościowe oraz zastawy towarów trwałych ${ }^{8}$. Wprowadzając do obiegu nowe, pod względem szaty graficznej, banknoty pozostawiono funkcjonujące w Imperium Rosyjskim wartości nominalne pieniędzy papierowych. Wynikało to z podpisanej przez Cesarstwo Niemieckie konwencji haskiej z 1907 roku, która zobowiązywała państwo okupujące do zachowania na okupowanych terenach - w miarę możliwości - dotychczasowego systemu pieniężnego'. Ostruble wydrukowano na papierze zabezpieczonym bieżącym znakiem wodnym ${ }^{10}$. Większość nominałów, z wyjątkiem sturublówki, została ozdobiona na awersach i rewersach rysunkiem ornamentalnym. Druk „,wykazów” odbywał się w różnych drukarniach, co spowodowało różnice $\mathrm{w}$ odcieniach kolorystycznych szaty graficznej banknotów ${ }^{11}$. Natomiast na najwyższym nominale znalazła się bardziej rozbudowana, w porównaniu z pozostałymi, szata graficzna. Z lewej strony awer-

6 L. Kokociński, Pieniadz papierowy na ziemiach polskich, Warszawa 1996, s. 66; W. Szaflik, op. cit., s. 12; C. Miłczak, Banknoty polskie i wzory, t. 2: Od 1944, Warszawa 2012, s. 330-338.

7 Tekst klauzuli dłuższej: Kto wykazy kasy pożyczkowej podrabia lub fatszuje albo o podrabiane lub sfałszowane się wystara i w obieg puszcza, karanym będzie domem karnym do ośmiu lat. Tekst klauzuli krótszej: Kto wykazy kasy pożyczkowej podrabia lub fatszuje albo podrabiane lub sfałszowane nabywa i puszcza je w obieg, karanym będzie domem karnym do ośmiu lat. C. Miłczak, op. cit., t. 2, s. 336.

8 A. Dylewski, Historia pieniądza na ziemiach polskich, Kraków 2012, s. 260-261.

9 W. Morawski, Od marki do złotego. Historia finansów Drugiej Rzeczpospolitej, Warszawa 2008 , s. 37.

10 Bieżący znak wodny jest to znak wodny wpisany w strukturę całej powierzchni papieru banknotu w postaci powtarzającego się rysunku geometrycznego lub ornamentu.

11 C. Miłczak, op. cit., t. 2, s. 332-360. 
su (il. 1 a) umieszczone zostało popiersie młodej kobiety w wieńcu z oliwek i diademie na głowie. Kobieta jest ubrana w rzymską tunikę ozdobioną pod szyją motywem astragalu. Po przeciwnej stronie projektant wkomponował popiersie brodatego mężczyzny w rzymskim hełmie na głowie. Ochronne nakrycie głowy zostało ozdobione ukazaną z profilu postacią sfinksa zaczerpniętą z mitologii greckiej, w której tym terminem określano potwora o kobiecej głowie i uskrzydlonym tułowiu lwa. Pomiędzy zwróconymi ku sobie popiersiami znajduje się cyfra nominału umieszczona w okrągłej, ozdobionej secesyjnymi motywami, ramie. Po obu stronach wkomponowane zostały girlandy owoców. Poniżej kobiecej i męskiej postaci umieszczono mięsiste, romboidalne ornamenty $\mathrm{w}$ postaci czteroliścia. $\mathrm{W}$ centrum ornamentu $\mathrm{z}$ prawej wkomponowane zostało winne grono, a po drugiej stronie stylizowany owoc granatu. Zespół atrybutów pozwala identyfikować kobiecą postać jako grecką boginię urodzaju Demeter (rzymska Ceres), a mężczyznę jako greckiego boga wojny Aresa (rzymski Mars). Natomiast na rewersie (il. 1 b) tego nominału umieszczono rysunek ornamentalny. $W$ centrum znalazło się owalne pole z wyrażoną za pomocą cyfry wartością nominału, które jest flankowane przez dwa mniejsze pola $\mathrm{z}$ ukazanymi profilowo głowami, zwróconymi ku sobie. Głowy te, w porównaniu z tymi z przedniej strony nominału, zostały ukazane w sposób bardziej schematyczny. Z lewej strony umieszczona została ukazana z prawego profilu głowa Hermesa (rzymski Merkury) w charakterystycznym uskrzydlonym kapeluszu. Natomiast z prawej strony projektant tego nominału wkomponował ukazaną z lewego profilu kobiecą głowę z długimi włosami i w wieńcu z gałązek oliwnych na skroniach. Obecność wieńca pozwala na interpretacje tego wizerunku jako przedstawienia Demeter. Banknoty sturublowe były drukowane w drukarni Rzeszy w Berlinie (Reichsdruckerei) $^{12}$. Nie są znani projektanci szaty graficznej banknotów, które Niemcy wprowadzili do obiegu na terenach Ober-Ostu.

Stabilizacja administracji wojskowej na terenach wschodnich skłoniła Niemców do zastąpienia ostrubla nową walutą. W związku z tym w 1918 roku przeniesiono siedzibę Wschodniej Kasy Pożyczkowej z Poznania do Kowna i wprowadzono do obiegu drugą emisję „wykazów”

12 Ibidem, s. 346. 


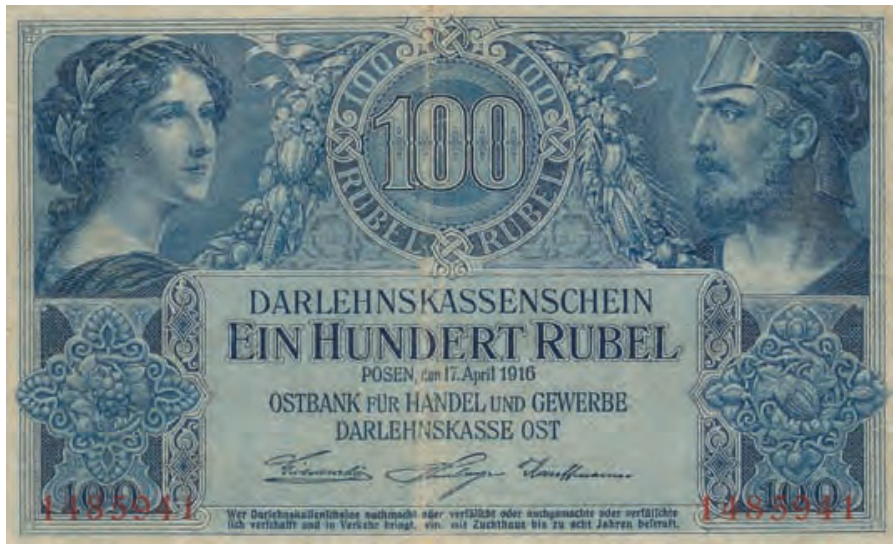

1 a. 100 rubli, 17 kwietnia 1916 (awers)

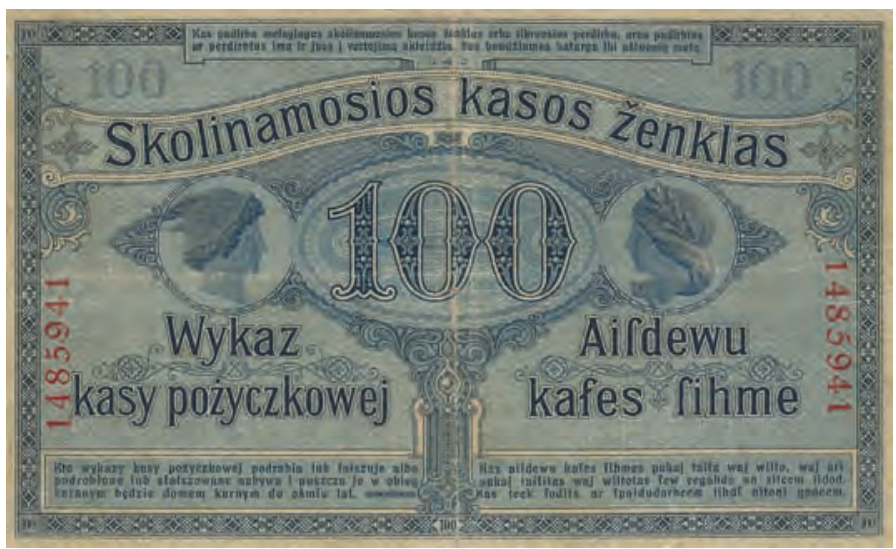

1 b. 100 rubli, 17 kwietnia 1916 (rewers)

tym razem $w$ walucie markowej. Na banknotach tych zniknęły napisy w języku polskim. Zmieniono miejsce i datę emisji. Zamiast: Poznań, 17 kwietnia 1916 roku, umieszczono: Kowno, 4 kwietnia 1918 roku. Zmianie uległy również podpisy członków zarządu Kasy. Zachowano natomiast znaki wodne. Banknoty o nominałach 20 kopiejek i 1/2 marki zostały zabezpieczone bieżącym znakiem wodnym w postaci siatki zachodzących na siebie rombów. Wzór ten przypomina kolczugę. Nominały 50 kopiejek, 1 rubel oraz 1 i 2 marki mają znak wodny w postaci kółek i umieszczonych pomiędzy nimi czteroramiennych gwiazdek. Papier banknotowy, na którym zostały wydrukowane pieniądze pa- 
pierowe o nominałach: 3, 10 i 25 rubli oraz 5, 20 i 50 marek, zabezpieczono skomplikowanym znakiem wodnym $\mathrm{w}$ postaci zahaczających się liter "Z" i sześcioramiennych gwiazd z umieszczonymi na przemian wewnątrz nich literami „,G” i „,D”. Litery te wskazują na drukarnię, która wykonała powyższe pieniądze papierowe - Typographisches Institut Giesecke [G] \& Devrient [D] w Lipsku. Najwyższe nominały zostały zabezpieczone znakiem wodnym w postaci ozdobnych rozet $^{13}$.

Mająca siedzibę w Kownie Wschodnia Kasa Pożyczkowa wpuściła do obiegu osiem różnych nominałów pieniędzy papierowych: 1/2, 1, 2, 5, 20, 50, 100 oraz 1000 marek. Marki te przeszły do historii jako „ostmarki” lub „marki wschodnie”. Przy projektowaniu tych „wykazów” posłużono się szatą graficzną ostrubli. Wskazuje to na jednego projektanta lub grupę projektantów tworzących projekty „wykazów Wschodniej Kasy Pożyczkowej" w rublach i markach. Nominały od 1/2 do 50 marek są $\mathrm{z}$ obydwu stron zdobione rysunkiem ornamentalnym. Szata graficzna nominału 5 marek została delikatnie przetworzona na potrzeby tego banknotu z 3 rubli (por. il. 2 a z il. 3 a oraz il. 2 b z il. 3 b). Podobna sytuacja miała miejsce w przypadku par banknotów 20 marek i 10 rubli oraz 50 marek i 25 rubli. W przypadku nominału 100 marek zmianie uległ kolor szaty graficznej banknotu z ciemnoniebieskiego na brązowy. Usunięto klauzulę prawną w języku polskim, lecz pozostawiono ogólny rysunek obydwu stron z postaciami mitologicznych bóstw.

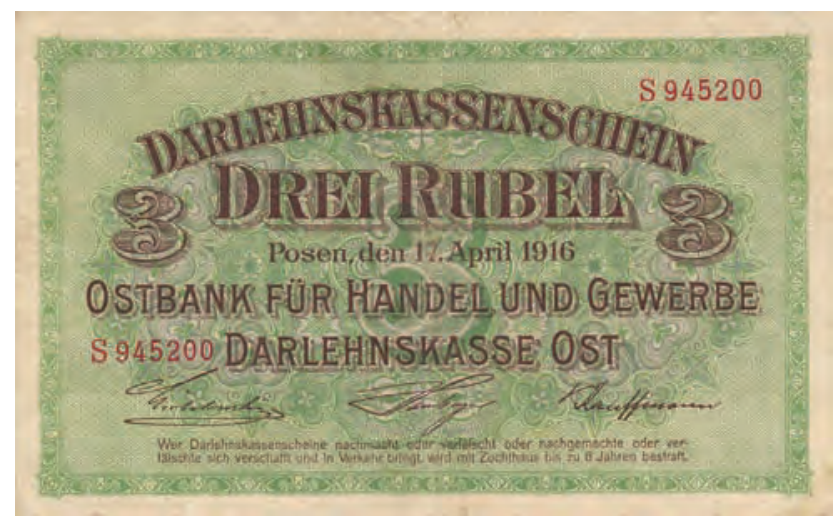

2 a. 3 ruble, 17 kwietnia 1916 (awers)

13 Ibidem, s. 332-366. 


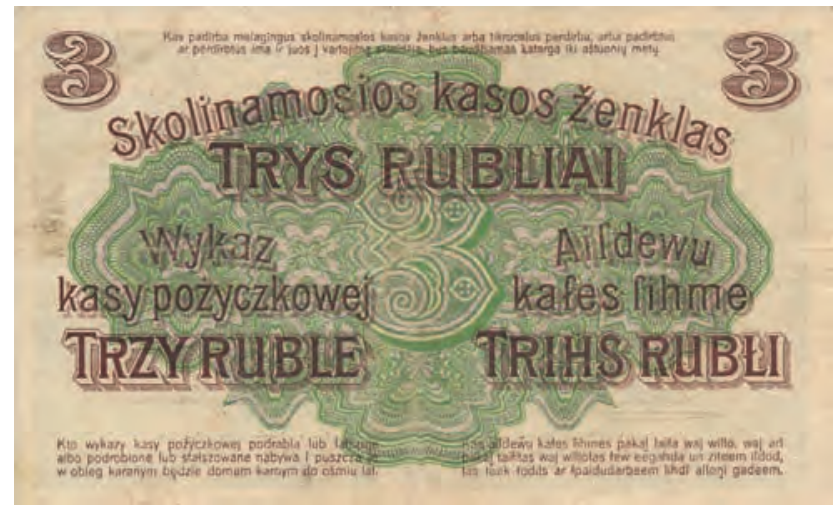

2 b. 3 ruble, 17 kwietnia 1916 (rewers)

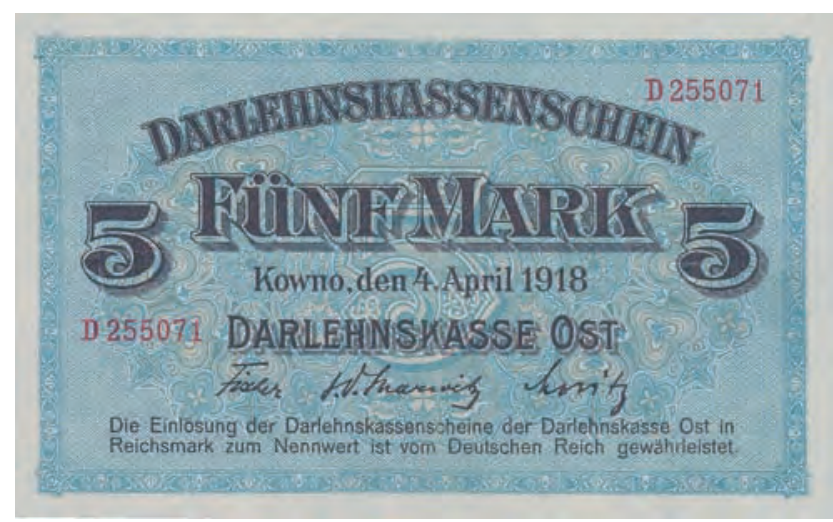

3 a. 5 marek, 4 kwietnia 1918 (awers)

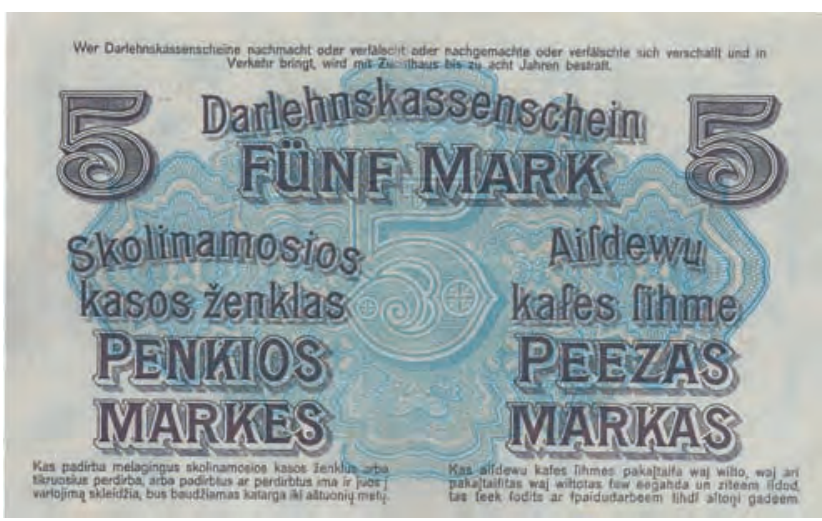

3 b. 5 marek, 4 kwietnia 1918 (rewers)

Źródło il. 3 a i 3 b: J. Parchimowicz, Katalog banknotów polskich i z Polska zwiąanych, wyd. 12, Szczecin 2013, s. 54. 
Natomiast całkiem nowym nominałem, którego szata graficzna nie miała odniesień do pieniędzy papierowych będących $\mathrm{w}$ obiegu na terenach okupowanych przez Niemcy podczas pierwszej wojny światowej, bylo 1000 marek. Centralne pole awersu (il. 4 a) zostało podzielone na dwie części pionowym pasem zwieńczonym głową lwa symbolizującą władzę, majestat i odwagę. Identyczne głowy znajdują się w górnych rogach stylizowanej ramy okalającej główną scenę awersu. Natomiast poniżej umieszczonych po bokach lwich głów znalazły się cesarskie ptaki - orły. Na awersie tego utrzymanego w zieleniach banknotu zostały umieszczone dwie męskie postacie - Hermes oraz mężczyzna w zbroi. Hermes został ukazany z lewego profilu $\mathrm{z}$ nagim torsem. W lewej ręce spoczywającej na stylizowanej secesyjnej ramie, wewnątrz której znajdują się informacje o nominale, mężczyzna trzyma laskę z oplecionymi wokół niej dwoma wężami. Na jego głowie znajduje się kapelusz z niespotykanie rozbudowanymi skrzydłami, które trudno znaleźć na przedstawieniach tego bóstwa na banknotach świata. Postaci antycznego boga handlu towarzyszy rycerz, który ma na głowie hełm przyozdobiony wieńcem laurowym. W prawej wyciągniętej przed siebie ręce mężczyzna trzyma trzon rękojeści miecza. Natomiast lewa ręka spoczywa na opartej o ziemię tarczy. Poprzez ubiór postać tę można utożsamiać z greckim bogiem wojny Aresem. Rycerz ma na sobie zbroję norymberską, która charakteryzowała się wydłużonymi konturami, smukłą sylwetką oraz bogatym żłobkowaniem. Na jego rękach znajdują się, stanowiące część uzbrojenia ochronnego, rękawice, a na głowie średniowieczny hełm. Umieszczona na głowie rycerza salada jest typowa dla hełmów tego typu wytwarzanych na terenach Niemiec. Tworzy ona harmonijną całość ze zbroja w którą artysta „ubrał” mężczyznę. Hełm ma ostrą grań, spiczasty nakarczek oraz długą poziomą szparę wzrokową ${ }^{14}$. Za mężczyznami znajduje się wisząca na poziomym karniszu jednobarwna tkanina obrębiona jasnym i ciemnym pasem. Obaj mężczyźni mają wzrok skierowany w stronę wschodzącego słońca umieszczonego w polu z lewej strony, w środku którego znajduje się wartość nominału. Okragłe pole z rysunkiem ornamentalnym wewnątrz okolone zostało promienistą poświatą. $W$ drugim polu została zakomponowana morska linia brzegowa z miastem porto-

${ }_{14}$ M. Gradowski, Z. Żygulski (jun.), Salada, w: iidem, Stownik uzbrojenia historycznego, wyd. 3, Warszawa 2010, s. 133. 
wym. W zabudowie miejskiej wyróżnia się bryła kościoła. Za miastem, na wysuniętym w morze cyplu, znajduje się latarnia morska. Natomiast w zatoce płyną trzy statki. Przedstawionych na awersie mężczyzn można interpretować jako strażników rozwoju handlu lokalnego oraz mieszkańców tego terenu. A wschodzące słońce jako symbol nowego porządku, który nastał wraz z przesunięciem się frontu na Wschód. Przedstawienie mężczyzn w średniowiecznej stylistyce nie jest wyjątkowe w przypad$\mathrm{ku}$ pieniędzy papierowych emitowanych w Cesarstwie Niemieckim. Na 20 markach emisji 11 lipca 1874 roku znalazł się wizerunek średniowiecznego herolda. Natomiast na 5 markach emisji 10 stycznia 1882 roku ubrany w zbroję turniejową rycerz ${ }^{15}$. Tylna strona banknotu 1000 marek emisji 4 kwietnia 1918 roku (il. 4 b) została podzielona pionowym pasem na dwie w miarę równe części. W większym $\mathrm{z}$ nich, umieszczonym z prawej strony, znalazła się wypisana po litewsku i łotewsku klauzula prawna. Pole to zostało ozdobione ornamentem roślinnym. W drugim polu projektant tego nominału umieścił widzianą od pasa w górę postać ubranej współcześnie młodej dziewczyny. Odziana w jasna, zwiewną bluzkę kobieta została ukazana frontalnie, z głową zwróconą w lewo. Związane z tyłu głowy włosy oraz oparty o prawe ramię młotek i trzymane w lewej

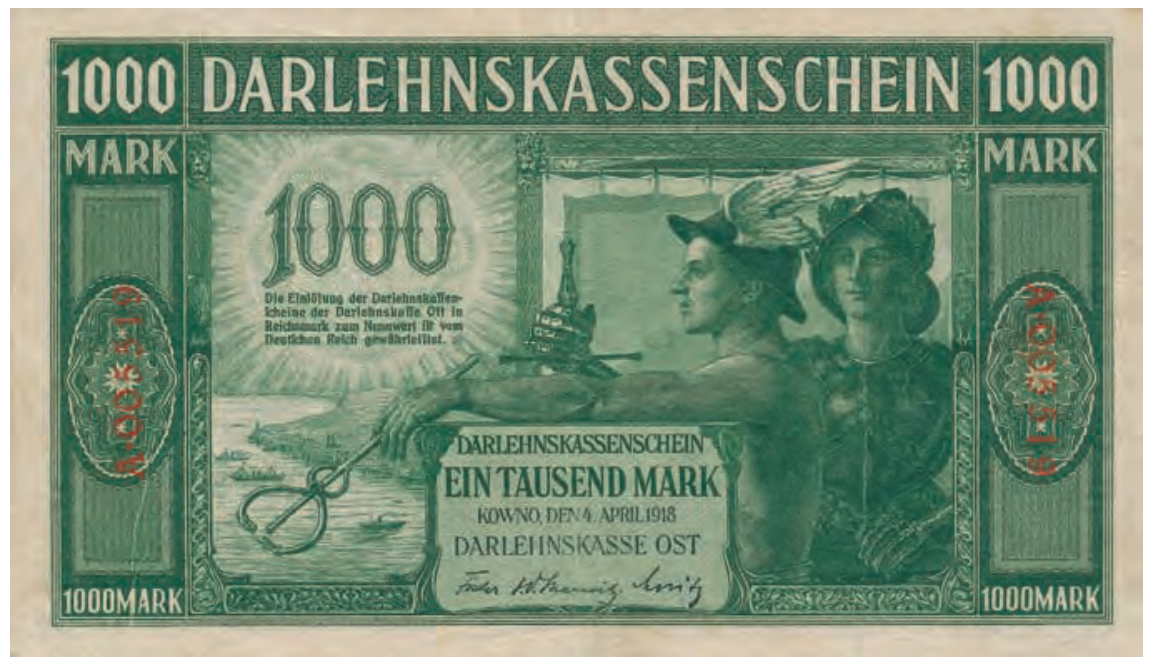

4 a. 1000 marek, 4 kwietnia 1918 (awers)

15 Standard Catalog of World Paper Money. General Issues 1368-1960 (red. G.S. Cuhaj), wyd. 12, Iola 2008, s. 555-556. 


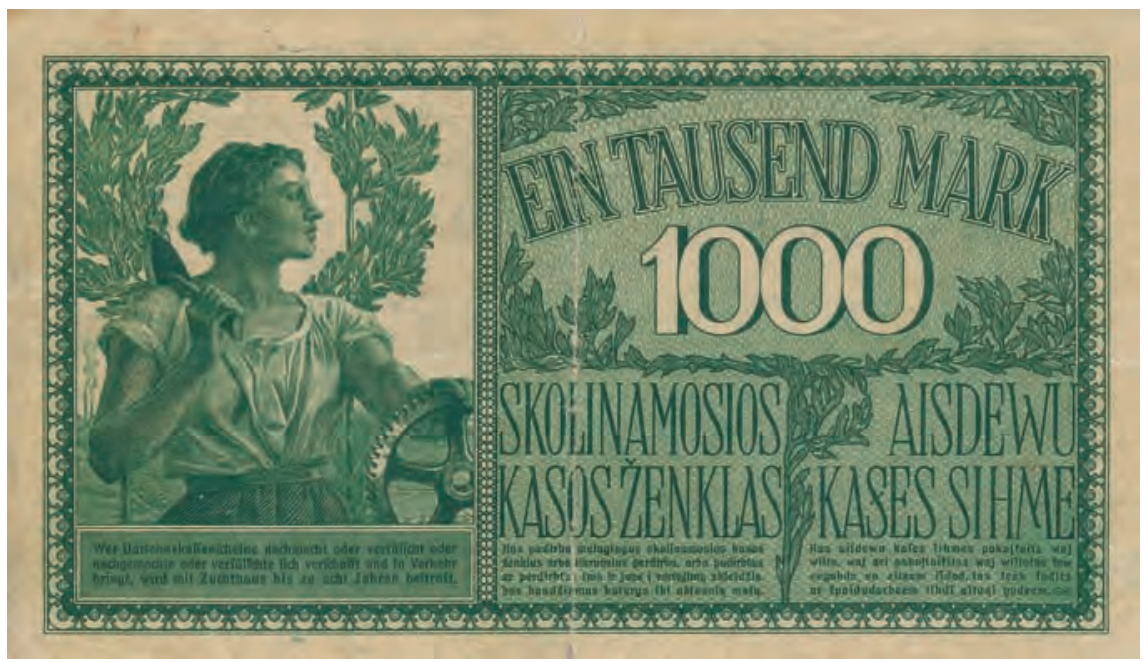

4 b. 1000 marek, 4 kwietnia 1918 (rewers)

ręce koło zębate pozwalają interpretować tę postać jako personifikację przemysłu. Głowa kobiety umieszczona została w swoistym nimbie, który tworzy wyrastający zza pleców kobiety wieniec laurowy. W tle zostały wkomponowane pola uprawne oraz dymiące kominy fabryczne.

Projekty i druk pieniędzy papierowych dla terenów Ober-Ostu został zlecony państwowej drukarni Reichsdruckerei w Berlinie oraz drukarni Gisecke \& Devrient w Lipsku. Natomiast najniższe nominały, do 1 rubla oraz do 2 marek, powstały w ramach zamówień złożonych w kilku prywatnych drukarniach niemieckich. Ostruble i ostmarki noszą cechy jednolitego projektu, a kilka z nich posiada identyczne gilosze, które różnią się kolorem i wartością nominału. Świadczy to o tym, że były projektowane przez jedną osobę lub grupę osób. Banknoty rublowe emitowane przez Wschodnią Kasę Pożyczkową były w obiegu niespełna dwa lata. Po zakończeniu pierwszej wojny światowej rubel stał się łotewską walutą tymczasową do końca 1923 roku, gdy do obiegu wprowadzono łata. Po odzyskaniu przez Litwę niepodległości utworzona przez Niemców Wschodnia Kasa Pożyczkowa została przekształcona w litewski bank emisyjny. W litewskim ustawodawstwie ostmarkę przemianowano na złotego (lit. auksinas), a feniga na skojca (lit. skatikas), jednak w obiegu w dalszym ciągu pozostały wprowadzone przez Niemców banknoty. 
Waluta ta została wycofana z końcem 1922 roku, gdy zastąpiono ją litem $^{16}$. Banknoty markowe emitowane przez Wschodnią Kasę Pożyczkową były w obiegu na północno-wschodnich terenach Królestwa Polskiego i późniejszej Drugiej Rzeczpospolitej do 30 listopada 1923 roku' ${ }^{17}$. Zarówno ostruble, jak i ostmarki były w obiegu na ziemiach, które weszły w skład odrodzonej 11 listopada 1918 Rzeczpospolitej, w związku $\mathrm{z}$ tym są one uwzględniane $\mathrm{w}$ przeznaczonych dla kolekcjonerów pieniądza papierowego katalogach banknotów polskich. Dodatkowo znajdujące się na ostrublach napisy w języku polskim pozwalają zaliczyć je do banknotów związanych z Polską.

Po wybuchu pierwszej wojny światowej rumuńska Rada Koronna dnia 5 sierpnia 1914 roku zadeklarowała zbrojną neutralność. Od tego momentu obie strony europejskiego konfliktu próbowały przeciągnąć Królestwo Rumunii na swoją stronę. Dla państw centralnych opowiedzenie się Rumunów po ich stronie oznaczałoby bezpośrednią komunikację z sojuszniczą Turcją, natomiast dla ententy uzyskanie lądowego połączenia z Serbią. Ważną kwestią dla obu stron były również dwa artykuły - zboże i nafta - w które było zasobne Królestwo Rumunii18.

Dnia 27 sierpnia 1916 roku Rumunia wypowiedziała wojnę Austro-Węgrom. Nastąpiło to w dziesięć dni po wygaśnięciu traktatu z 1883 roku, na mocy którego Królestwo Rumunii zobowiązało się do współpracy z Cesarstwem Niemieckim i Austro-Węgrami. Następnego dnia Niemcy wypowiedzieli wojnę Rumunii, 30 sierpnia zrobiła to Turcja, a 1 września Bułgaria. Jeszcze w tym miesiącu 3/4 rumuńskiej armii zaatakowało austro-węgierski Siedmiogród, zajmując jego większą część. W zamian za ten manewr ententa obiecała Rumunii korzyści terytorialne $\mathrm{w}$ postaci ziem wchodzących w skład monarchii Habsburgów - Siedmiogród, Bukowinę i Banat. Wkrótce nastąpiła kontrofensywa wojsk austro-węgierskich, bułgarskich i niemieckich. We wrześniu wojska rumuńskie poniosły klęskę w Dobrudży, tracąc Tutrakan i Silistrę, a następnie Konstancę. Dzięki pomocy wojsk rosyjskich udało się za-

\footnotetext{
16 A. Dylewski, op. cit., s. 261; Standard Catalog..., s. 798-800; 813.

17 L. Kokociński, op. cit., s. 66; W. Szaflik, op. cit., s. 12; C. Miłczak, op. cit., t. 2, s. 330 .

18 J. Pajewski, op. cit., s. 369; M. Willaume, Rumunia, Warszawa 2004, s. 71-72.
} 
trzymać ofensywę państw centralnych na linii dolnego Dunaju. Dnia 6 grudnia 1916 roku został zdobyty Bukareszt, a pod koniec roku ocalałe oddziały rumuńskie wycofały się do Mołdawii. Do Rosji zostały ewakuowane zakłady zbrojeniowe, a szyby naftowe zniszczone. Po bitwie pod Putna i utracie 6 stycznia 1917 roku Fokszan front zatrzymał się na linii: ujście Dunaju-Seret-Trotus-wschodnie stoki południowych Karpat. Król Ferdynand I wraz z rządem schronili się w Jassach na terytorium Rosji. W wyniku działań wojennych Królestwo Rumunii utraciło blisko 70\% swego terytorium i połowę z sześćsettysięcznej armii ${ }^{19}$. Latem 1917 roku wojska niemieckie wznowiły ofensywę, dążąc do zajęcia reszty Królestwa. Od lipca do października trwały zacięte walki zakończone sukcesem obrony rumuńsko-rosyjskiej. W końcu lipca armia rumuńska odparła nieprzyjaciela na Bukowinie. Jesienią w Rosji doszło do rewolucji październikowej. Zwycięstwo partii bolszewickiej, która dążyła do zawarcia pokoju, przesądziło los frontu w Rumunii. Dodatkowo sytuacja w niezajętej części kraju stała się niebezpieczna dla rządu. Przemęczona wojna, wygłodzona i zniechęcona ludność ujawniała coraz groźniejszą postawę. W Besarabii szerzył się żywiołowo ruch rewolucyjny, W związku z tym, za zgodą ententy, dnia 9 grudnia 1917 roku podpisano zawieszenie broni pomiędzy Królestwem Rumunii a państwami centralnymi ${ }^{20}$.

Na okupowanych przez wojska niemieckie terenach Rumunii wprowadzono do obiegu nowe wzory pieniędzy papierowych, pozostawiając dzielonego na 100 bani leja. Banknoty te zostały wprowadzone do obiegu w styczniu 1917 roku. Emitentem ich był utworzony w porozumieniu z Bankiem Rzeszy rumuński bank - Banca Generala Româna ${ }^{21}$. Było to spowodowane ewakuacją Banca Nationalâ a Românei z zapasami złota i archiwaliami do Jassy22. Emisja składała się z ośmiu nominałów od 25 bani do 1000 lei. Wszystkie pieniądze papierowe wprowadzone do

${ }^{19}$ J. Pajewski, op. cit., s. 371; M. Willaume, op. cit., s. 75-79; J. Demel, Historia Rumunii, Wrocław - Warszawa - Kraków 1970, s. 370-371.

${ }^{20}$ J. Demel, op. cit., s. 372-373; M. Willaume, op. cit., s. 80-84. s. 288.

21 J. Koziczyński, Banknoty polskie. Kolekcja Lucow, t. 3: 1916-1923, Warszawa 2002,

22 Historical Overview, w: Banca Nationalâ a Românei, http://www.bnr.ro/HistoricalOverview-7212.aspx [dostęp: 28 października 2014]. 
obiegu na okupowanych terenach Królestwa Rumunii zostały ozdobione rysunkiem ornamentalnym oraz umieszczonymi w medalionach męskimi i kobiecymi głowami. Jednak brakuje na nich daty i miejsca emisji.

Wyemitowane przez Banca Generala Româna banknoty pod względem stylistycznym można podzielić na trzy grupy. Pieniądze papierowe należące do pierwszej z nich charakteryzują się obecnością jednego medalionu z profilowo ukazaną głową na awersie. Do grupy tej należą dwa najniższe nominały - 25 i 50 bani. Z prawej strony awersu 25 bani (il. 5) zostało wkomponowane ukazane z lewego profilu popiersie Merkurego w uskrzydlonej czapce oraz spiętej na lewym ramieniu chlamidzie ${ }^{23}$. Natomiast $\mathrm{z}$ lewej strony awersu nominału 50 bani (il. 6) została wkomponowana kobieca głowa ukazana z prawego profilu.

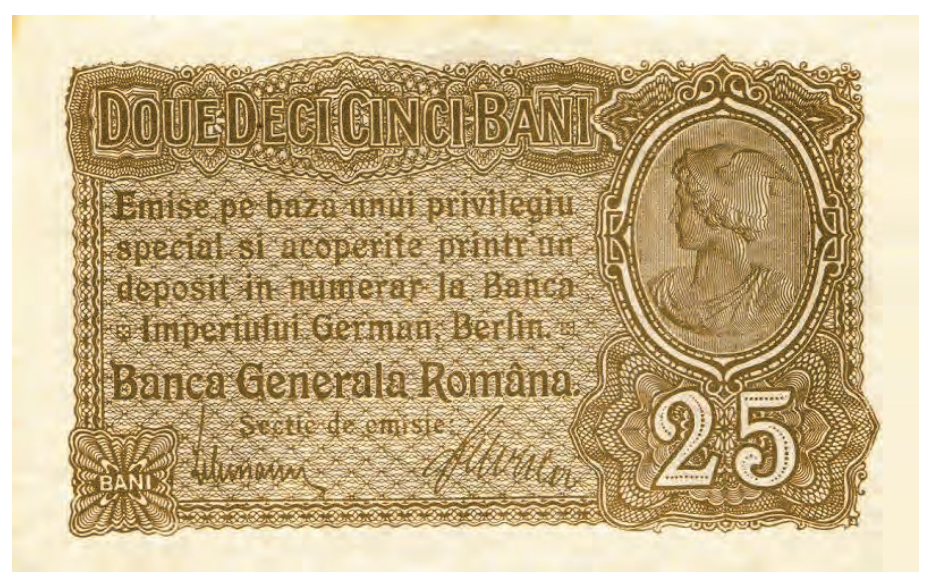

5. 25 bani [1917] (awers)

${ }^{23}$ Noszona w starożytnej Grecji przez jeźdźców i podróżnych krótka, wierzchnia szata męska. Był to prostokątny pas materiału o trzech rogach prostych i czwartym zaokrąglonym. Najczęściej był spinany fibulą na prawym ramieniu lub pod brodą. Obok kaduceusza, uskrzydlonej czapki (petasos), uskrzydlonych sandałów oraz sakiewki chlamida należy do atrybutów Hermesa. Chlamida, w: Stownik terminologiczny sztuk pięknych (red. K. Kubalska-Sulkiewicz, M. Bielska-Łach, A. Manteuffel-Szarota), wyd. 4, Warszawa 2003, s. 69; Hermes, w: Encyklopedia sztuki starożytnej. Europa, Azja, Afryka, Ameryka (red. A. Drewnojadowa, A. Dulewicz, B. Grochala), Warszawa 1998, s. 280; J. Sachse, Hermes, w: P. Grimal, Stownik mitologii greckiej i rzymskiej, wyd. 2, Wrocław - Warszawa - Kraków 1990, s. 141-142; K. Marciniak, Mitologia grecka i rzymska, bohaterowie ponad czasem, Opowieść o bogach $i$ herosach, konteksty kulturowe, historia i wspótczesność, Warszawa - Bielsko-Biała 2010, s. 269. 


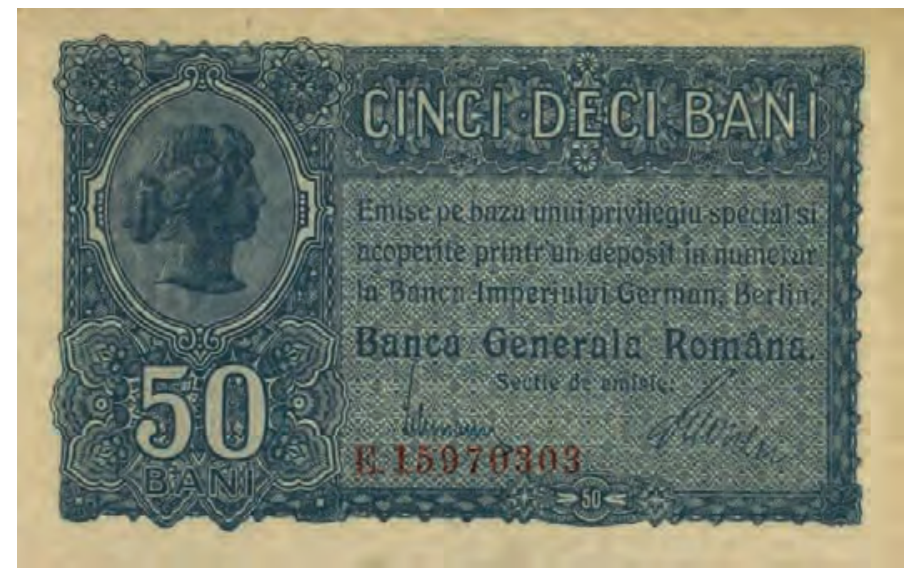

6. 50 bani [1917] (awers) 2014].

Źródło il. 5 i 6: http://banknoteworld.com/romania?Date=1917 [dostęp: 12 grudnia

Do drugiej grupy zaliczają się trzy nominały: 1, 2 i 5 lei. W przypad$\mathrm{ku}$ tych pieniędzy papierowych projektanci wkomponowali na awersach po dwa medaliony ze zwróconymi ku sobie popiersiami. W polu z lewej awersu banknotu o nominale 1 lej (il. 7) umieszczony został wizerunek Merkurego ubranego w chlamidę i uskrzydloną czapkę. Natomiast $\mathrm{w}$ polu $\mathrm{z}$ prawej znalazło się kobiece popiersie $\mathrm{z}$ długimi włosami przyozdobione wieńcem laurowym na skroniach. Z lewej strony

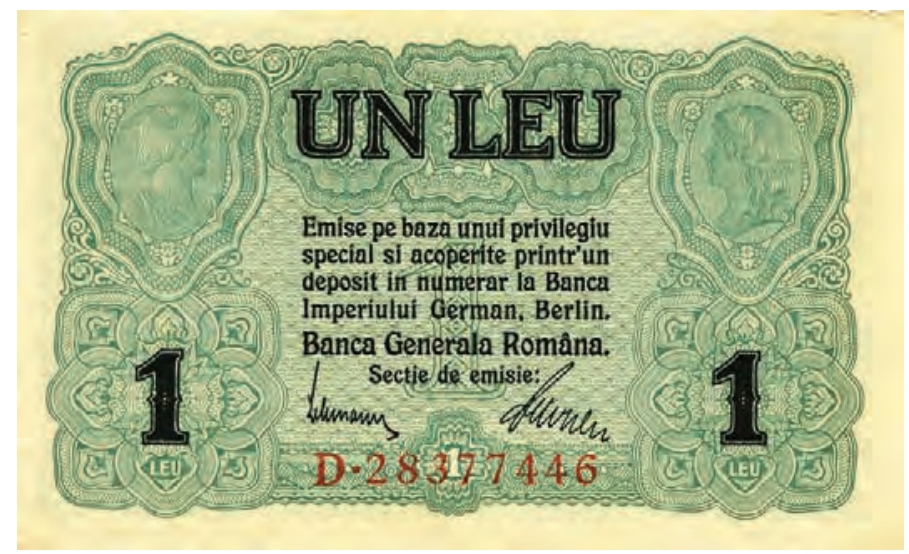

7. 1 lej [1917] (awers)

Źródło: http://banknoteworld.com/romania?Date=1917 [dostęp: 12 grudnia 2014]. 
awersu nominału 2 lei (il. 8) wkomponowane zostało ukazane z prawego profilu popiersie kobiety z włosami upiętymi w kok. Natomiast po przeciwnej stronie $\mathrm{w}$ owalnym polu umieszczona została głowa Merkurego w uskrzydlonej czapce. Na awersie 5 lei wkomponowano dwa kobiece popiersia z upiętymi z tyłu w kok włosami.

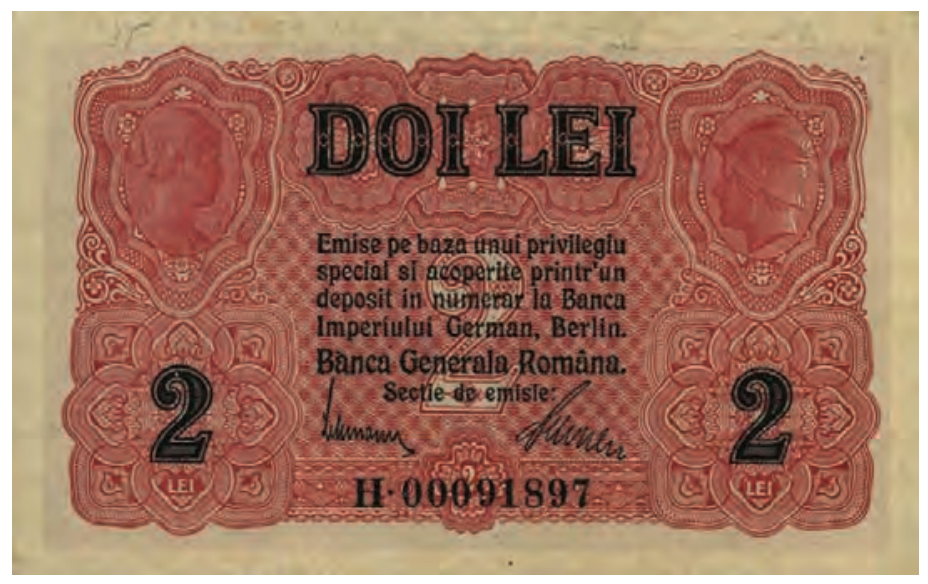

8. 2 lei [1917] (rewers)

Źródło: http://banknoteworld.com/romania?Date=1917 [dostęp: 12 grudnia 2014].

Do trzeciej grupy zaliczają się trzy najwyższe nominały Banca Generala Româna: 20, 100 i 1000 lei. W przypadku tych banknotów medaliony zostały wkomponowane na rewersach. W polu z lewej banknotu o nominale 20 lei znajduje się ukazana profilowo kobieca postać ubrana w chiton z włosami spiętymi z tyłu głowy. Na jej skroniach umieszczony został wieniec z kłosów zbóż. Obecność tego atrybutu pozwala interpretować tę postać jako przedstawienie antycznej bogini urodzaju Demeter. Natomiast $\mathrm{w}$ drugim medalionie zostało umieszczone przedstawienie Merkurego ubranego w chiton i uskrzydloną czapkę. Te same popiersia zostały umieszczone $\mathrm{w}$ medalionach na rewersie banknotu o nominale 100 lei. Z tym, że w przypadku wyższego nominału projektujący go artysta zamienił je miejscami i przedstawił w lustrzanym odbiciu względem układu z 20 lei. W polu z lewej najwyższego nominału (il. 9) przeznaczonego dla okupowanych terenów Królestwa Rumunii została wkomponowana kobieca głowa w wieńcu laurowym na głowie. Lu- 
strzane odbicie tego portretu zostało umieszczone na rewersie 100 rubli emisji 17 kwietnia 1916 (por. il. 10 z il. 11) i 100 marek emisji 4 kwietnia 1918 roku, które były przeznaczone dla terenów Ober-Ostu. Natomiast w drugim medalionie umieszczona została głowa brodatego mężczyzny w czapce frygijskiej. Portret ten został wykorzystany później na awersie niemieckiego banknotu o nominale 500000 marek emisji 1 maja 1923 roku, który trafił do obiegu w okresie hiperinflacji (por. il. 23 z il. 24).

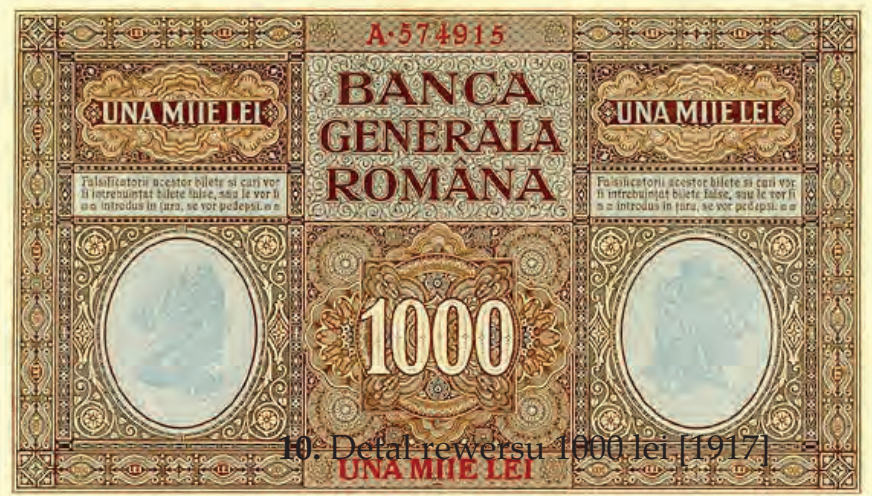

9. 1000 lei [1917] (rewers)

Źródło: http://banknoteworld.com/romania?Date=1917 [dostęp: 12 grudnia 2014].

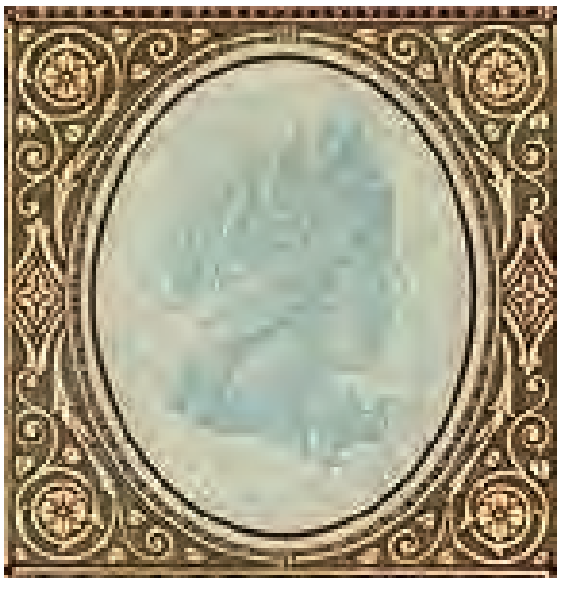

10. Detal rewersu 1000 lei [1917]

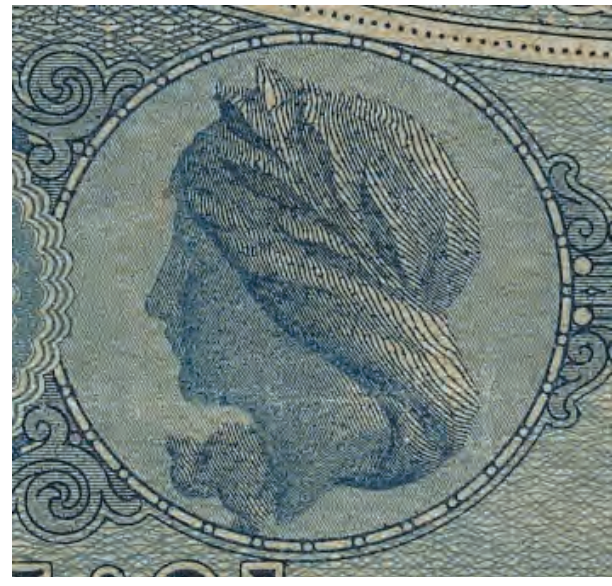

11. Detal rewersu 100 rubli, 17 kwietnia 1916 
W sierpniu 1915 roku na części terytorium Imperium Rosyjskiego okupowanego przez armię niemiecką utworzono Generał-Gubernatorstwo Warszawskie. Dnia 26 sierpnia cesarz Wilhelm II mianował generał-gubernatorem pruskiego generała piechoty Hansa von Beselera, który w październiku 1914 roku zasłynął jako zdobywca belgijskiej twierdzy w Antwerpii ${ }^{24}$. W tym samym czasie na ziemiach okupowanych przez wojska austro-węgierskie, decyzją cesarza Franciszka Józefa I, utworzono Generał-Gubernatorstwo Lubelskie. Na siedzibę administracji austro-węgierskiej strefy okupacyjnej wybrano Lublin. Od sierpnia 1915 do listopada 1918 roku urząd ten sprawowali czterej kolejni generał-gubernatorzy: Erich von Diller, Karl von Kuk, Stanisław Szeptycki oraz Anton Lipoščak ${ }^{25}$.

Dnia 5 listopada 1916 roku generał-gubernatorzy obu stref okupacyjnych, Hans von Beseler i Karl von Kuk, w imieniu cesarzy Wilhelma II i Franciszka Józefa I ogłosili Akt 5 listopada. Wydany przez władze okupacyjne dokument gwarantował Polakom utworzenie Państwa Polskiego o niesprecyzowanych granicach, lecz z własną armią. Proklamowanie odrębnego od Rosji państwa było jedynym sposobem na pozyskanie przez Austrię i Niemcy rekruta ${ }^{26}$. Wynikało to z konwencji haskiej z 1907 roku, w której była mowa o tym, że na terenach zajętych państwo okupujące nie może prowadzić poboru do wojska ${ }^{27}$. Natomiast okupowane przez wojska niemieckie i austriackie Królestwo Polskie było okupowaną częścią Rosji ${ }^{28}$. Powstałe pod egidą państw centralnych Państwo Polskie miało być monarchią konstytucyjną ściśle im podporządkowaną 29 . Na czele nowego tworu państwowego stanę-

${ }^{24}$ J. Koziczyński, op. cit., s. 18; W. Morawski, op. cit., s. 34; M. Markowski, op. cit., s. $99-100$.

25 Ilustrowany atlas historii Polski, red. W. Sienkiewicz, E. Olczak, t. 4: Pod zaborami, Warszawa 2007, s. 98; M. Markowski, op. cit., s. 99-100.

26 Ewakuujący się z Królestwa Polskiego Rosjanie przeprowadzili dość pobieżny pobór do wojska. W związku z tym na terenach okupowanych przez Austro-Węgry i Niemcy rezerwę rekruta szacowano na około milion żołnierzy. W. Morawski, op. cit., s. 38.

27 Jednak nadzieje na pozyskanie rekruta zawiodły, ponieważ pobór do wojska mogły zarządzić jedynie polskie władze. Natomiast Tymczasowa Rada Stanu, przekształcona później w Radę Regencyjna, nie zamierzała dawać Niemcom takiego prezentu. Ibidem.

28 Ibidem, s. 37.

29 T. Nałęcz, Wielka wojna, w: H. Samsonowicz, J. Tazbir, T. Łepkowski, T. Nałęcz, Polska. Losy państwa i narodu do 1939 roku, wyd. 6, Warszawa 2003, s. 453-454. 
ła trzyosobowa Rada Regencyjna, jednak faktyczna władza pozostała w rękach obsadzonego przez Niemców Zarządu Generał-Gubernatorstwa Warszawskiego ${ }^{30}$. Na mocy rozporządzenia z 9 grudnia 1916 roku niemieckie władze okupacyjne utworzyły w Generał-Gubernatorstwie Warszawskim instytucję emisyjną - Polską Krajową Kasę Pożyczkową której otwarcie nastąpiło 26 kwietnia 1917 roku $^{31}$. Pomimo swej nazwy Polska Krajowa Kasa Pożyczkowa nie była polską instytucją emisyjna, lecz agendą Banku Rzeszy - podobnie jak Banca Generala Româna ${ }^{32}$. Utworzona przez władze niemieckie instytucja była emitentem marki polskiej dzielonej na sto fenigów. Proklamowanie nowego państwa było również sposobem na ominięcie zapisu konwencji haskiej z 1907 roku, która zobowiązywała okupanta do pozostawienia dotychczasowego systemu monetarnego. Kurs nowej waluty został zrównany z kursem marki niemieckiej33. Do obiegu, podobnie jak w Ober-Oscie, wprowadzono żelazne monety. Na ich awersach umieszczono orła polskiego, a na rewersie nominał oraz datę emisji. Według rozporządzenia generał-gubernatora miały to być nominały: 5, 10 i 20 fenigów $^{34}$. Monety te były wybijane w 1917 i 1918 roku w mennicy w Stuttgar$\mathrm{cie}^{35}$. W drugim roku bicia dodano nominał 1 fenig. Natomiast występująca $\mathrm{w}$ literaturze przedmiotu jednofenigówka wybita $\mathrm{w}$ roku 1917 jest najprawdopodobniej monetą próbną ${ }^{36}$. Pieniądze papierowe zostały wprowadzone do obiegu dnia 26 kwietnia 1917 roku. Rzesza Niemiecka gwarantowała spłatę marek polskich do wysokości miliarda

30 A. Schmidt, Kształtowanie polskiego systemu pieniężnego po 11 listopada 1918 r., „Biuletyn Numizmatyczny" 1994, nr 3, s. 3; A. Dylewski, op. cit., s. 260.

31 M. Gumowski, Pieniądz papierowy Polski Odrodzonej, „Wiadomości Numizmatyczno-Archeologiczne" 1939, t. 20, s. 155.

32 A. Dylewski, op. cit., s. 260.

33 T. Gruszecki, Pieniadz w dziejach gospodarczych Polski, Lublin 2003, s. 29-30; M. Kowalski, Zarys historii polskiego pieniadza papierowego (1916-1939), „Wiadomości Numizmatyczne" 1966, z. 1, s. 33; H. Cywiński, Dziesięć wieków pieniądza polskiego 980-1980, Warszawa 1982, s. 183-185; M. Gumowski, Pieniądz papierowy...., s. 155-156; W. Morawski, op. cit., s. 38-39.

${ }_{34}$ M. Gumowski, Nowa moneta polska, „Wiadomości Numizmatyczno-Archeologiczne" 1917, nr 6 i 7, s. 205.

35 Po obu stronach ogona przedstawionego na awersie orła zostały umieszczone litery „F-F” będące znakiem mennicy wirtemberskiej w Stuttgarcie. T. Kałkowski, Tysiac lat monety polskiej, wyd. 3, Kraków 1981, s. 401; W. Szaflik, op. cit., s. 14.

36 W. Szaflik, op. cit., s. 14. 
marek $^{37}$. Niemcy przygotowali dwie emisje marek polskich. Pierwsza, zwana potocznie przez kolekcjonerów ,"jenerał" ${ }^{38}$, składała się z sześciu nominałów: 1/2, 1, 2, 20, 50 i 100 marek polskich. Niestety wydrukowane w Rzeszy banknoty mialy błędy składniowe ${ }^{39}$, w związku z tym powtórnie wydrukowano banknoty, dodając trzy nowe nominały: 5, 10 i 1000 marek polskich ${ }^{40}$. Druga emisja, nazywana przez kolekcjonerów "generał", została wyemitowana pomiędzy lipcem a listopadem 1917 roku, z wyjątkiem najwyższego nominału, który trafił na rynek w styczniu 1918 roku. Banknoty te pozostały prawnym środkiem płatniczym w Polsce po zakończeniu pierwszej wojny światowej do 30 listopada 1923 roku $^{41}$. Pieniądze papierowe dla Polskiej Krajowej Kasy Pożyczkowej były drukowane w berlińskiej państwowej wytwórni Banku Rzeszy (Reichsdruckerei) oraz w prywatnej drukarni Giescecke \& Devrient w Lipsku ${ }^{42}$. Na awersie każdego z nominałów, w stylizowanym manierystycznym kartuszu, został umieszczony wizerunek Orła Białego na intensywnym czerwonym tle, który został adaptowany na potrzeby polskich pieniędzy papierowych z renesansowego wzoru. Przy projektowaniu tych pieniędzy papierowych współpracowali polscy artyści ${ }^{43}$. Dodatkowo na awersie każdego z nominałów znajduje się czerwona winieta z pieczęcią Zarządu Generał-Gubernatorstwa Warszawskiego.

37 T. Kałkowski, op. cit., s. 402; L. Kokociński, op. cit., s. 70.

38 Po wprowadzeniu tej serii do obiegu okazało się, że w szacie graficznej tych banknotów znajdują się poważne błędy w pisowni, które wynikały z faktu wykonania ich przez niemieckich grafików pracujących w berlińskiej drukarni. J. Koziczyński, op. cit., s. 18-19.

39 W szacie graficznej pierwszej emisji znalazła się nazwa Gubernatorstwa: Zarząd jenerat-gubernatorstwa warszawskiego, która została poprawiona w drugiej emisji na: Zarząd Generał-Gubernatorstwa Warszawskiego. Na banknotach serii ,jenerał” nazwa emitenta została zapisana w formie: krajowa polska Kasa Pożyczkowa (w klauzuli prawnej skrócona do: Kasy Pożyczkowej), która następnie została poprawiona na: Polska Krajowa Kasa Pożyczkowa. (por. il. 17 a z il. 16 a oraz il. 17 b z il. 16 b). T. Wodzyński, Banknoty polskie - typy i odmiany. Katalog 1794-2002, Warszawa 2002, s. 55.

40 Znane są druki próbne banknotów o nominałach 5 i 10 marek polskich serii ,jenerał” z perforacją "DRUCKPROBE” i numeracją zerową. Szata graficzna tych pieniędzy papierowych nie różni się od wprowadzonych do obiegu nominałów z poprawionymi błędami składniowymi. C. Miłczak, Banknoty polskie i wzory, t. 1. 1794-1941, Warszawa 2012, s. 152.

41 C. Miłczak, op. cit., t. 1, s. 162-184.

42 Ibidem, s. 144.

43 M. Gumowski, Nowa moneta..., s. 203. 
Na rewersach marek polskich znalazły się po dwa pola z przedstawieniami głów. Pod względem wyglądu szaty graficznej banknoty przeznaczone dla Generał-Gubernatorstwa są podobne do tych przygotowanych dla okupowanych terenów Królestwa Rumunii. Obie emisje zostały wydrukowane w Reichsdruckerei. W obu widać wyraźne podobieństwo w kompozycji giloszy, w układzie graficznym, jak również w użyciu kilku identycznych głów umieszczanych w medalionach. Bilety dla Polskiej Krajowej Kasy Pożyczkowej oraz dla Banca Generala Româna drukowano na papierze zabezpieczonym tym samym znakiem wodnym.

Zaprojektowane przez niemieckich grafików banknoty przeznaczone dla Polskiej Krajowej Kasy Pożyczkowej, podobnie jak banknoty Banca Generala Româna, można podzielić na trzy typy. Pierwszy z nich obejmuje trzy najniższe nominały: 1/2, 1 i 2 marki polskie, gdzie awers został podzielony na dwie części (il. 12 a). W węższej z nich, umieszczonej z lewej strony, wkomponowany został stylizowany manierystyczny kartusz ozdobiony ornamentami zwijanymi i zwieńczony zamkniętą koroną. W rogach tej części nominału zostały umieszczone kompozycje z owoców i liści, które pełnią funkcje dekoracyjne. Szersze pole zostało przeznaczone na informacje o nominale oraz klauzulę prawną. U góry znajduje się prostokątny kartusz ozdobiony ornamentami zwijanymi. Wewnątrz niego umieszczone zostało czerwone pole z wyrażoną słownie wartością nominału. Natomiast rewersy (il. 12 b) zostały podzielone na trzy części. W polu środkowym znajduje się rysunek

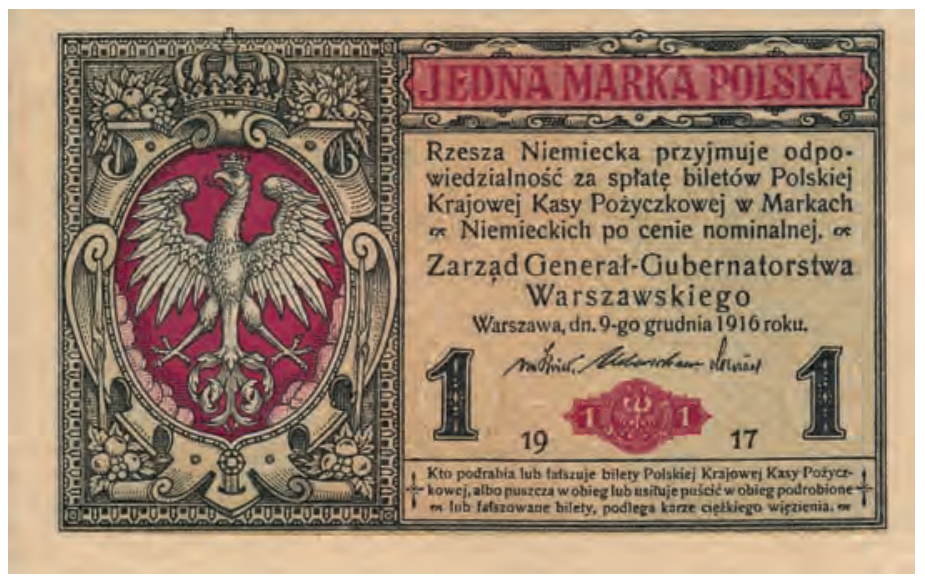

12 a. 1 marka polska, 9 grudnia 1916 (awers) 
ornamentalny z powtórzoną trzykrotnie w wersji liczbowej wartością nominału. Pośrodku każdego z bocznych, węższych, pól został wkomponowany owalny medalion ozdobiony u góry i dołu dekoracją roślinną. Wewnątrz medalionów zostały wkomponowane kobiece popiersia zwrócone twarzami do siebie. Głowy z rewersu banknotu o nominale 1/2 marki polskiej są identyczne $\mathrm{z}$ kobiecym portretem $\mathrm{z}$ awersu rumuńskiego banknotu o nominale 1 lej (por. il. 17 z il. 18). Pewne podobieństwa w schemacie kompozycyjnym szaty graficznej awersów trzech najniższych nominałów marek polskich można odnaleźć na awersie banknotu 5 marek emisji 1 sierpnia 1917 roku (por. il. 12 a z il. 15) wyemitowanym przez niemiecką Kasę Pożyczkową w celu zastąpienia monet srebrnych. Tak jak w przypadku trzech najniższych nominałów marek polskich również w przypadku tego pieniądza papierowego awers został podzielony na dwa pola. Pole szersze $z$ informacjami o banknocie znajduje się, inaczej niż na markach polskich, z lewej strony. Z tym, że pole węższe znalazło się z prawej strony nominału. $W$ miejscu manierystycznego kartusza został wkomponowany owalny medalion z kobiecym portretem. Poprzez umieszczony w jej włosach wieniec z kłosów zbóż i kwiatów postać tę można identyfikować z grecką boginią urodzaju - Demeter. Zbliżony schemat kompozycyjny awersu znajdziemy również w przypadku banknotów 25 i 50 bani emitowanych przez Banca Generala Româna (por. il. 5 z il. 12 a oraz il. 15). Awersowi niższego z nominałów bliżej jest do pięciomarkówki,

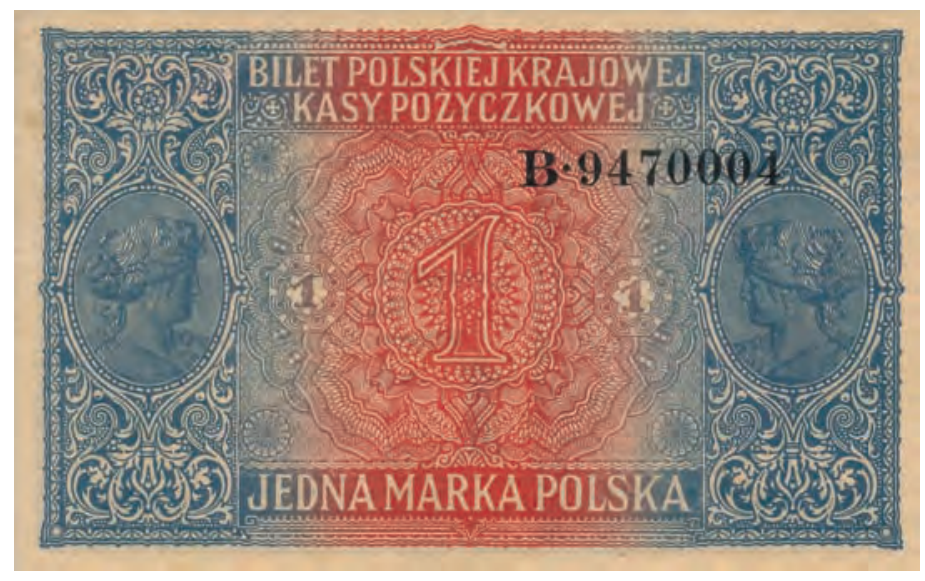

12 b. 1 marka polska, 9 grudnia 1916 (rewers) 
a wyższemu do marek polskich. W przypadku banknotów przeznaczonych dla okupowanego terytorium Królestwa Rumunii oraz 5 marek $\mathrm{w}$ owalnym medalionie znalazło się popiersie, a poniżej gilosz z wyrażoną za pomocą liczby wartością nominału.

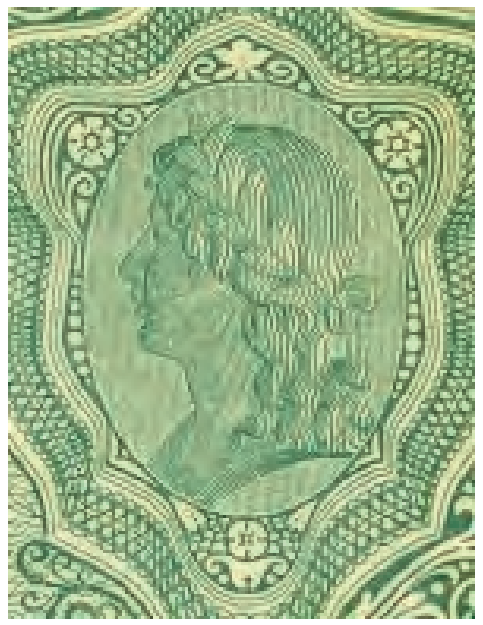

13. Detal z awersu 1 lej [1917]

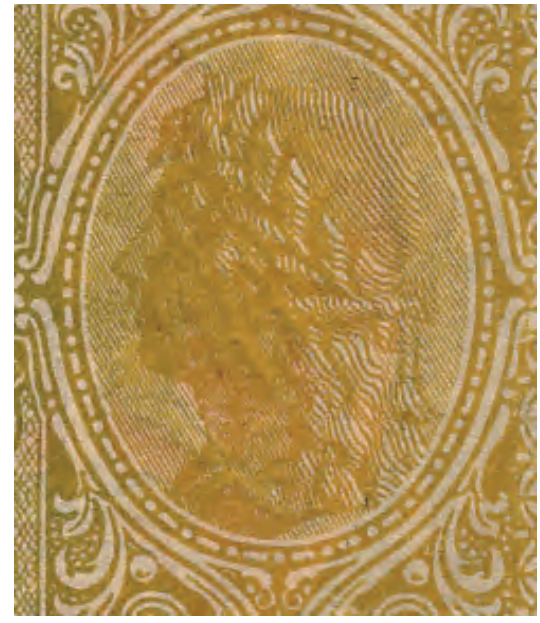

14. Detal z rewersu 1/2 marki polskiej, 9 grudnia 1916

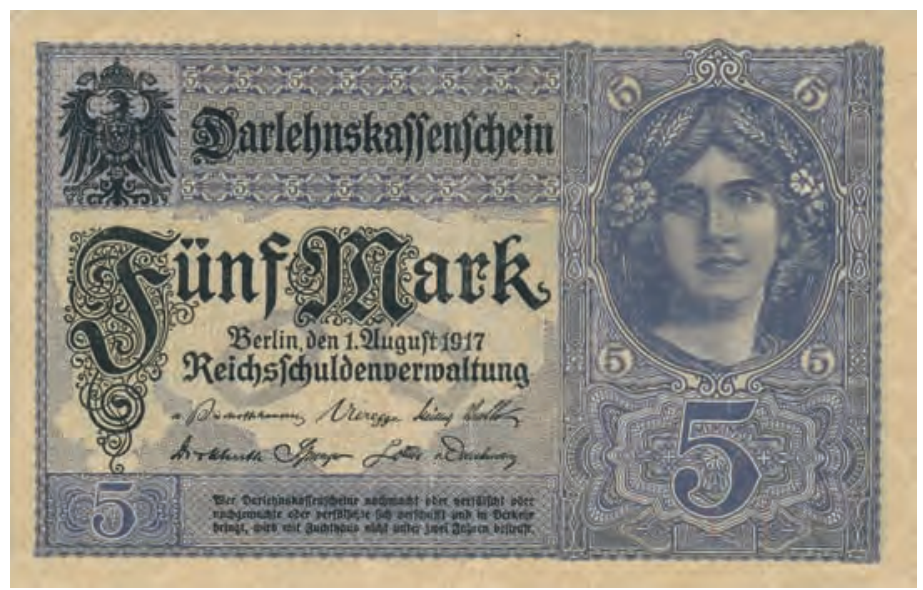

15. 5 marek, 21 sierpnia 1917 (awers)

Nominały 5, 10, 20 oraz 50 marek polskich reprezentują drugi typ użytego wzoru. Zmianie uległa dekoracja manierystycznego kartusza, który na tych nominałach jest centralnym punktem awersu (il. 16 a 
i il. 17 a). Umieszczony u góry ornament zwijany rozchodzi się symetrycznie na boki. W górnych rogach, $\mathrm{w}$ mniejszych prostokątnych kartuszach, znalazła się wyrażona za pomocą liczb wartość nominału. Rewersy tych pieniędzy papierowych również zostały zakomponowane według jednego schematu (il. 16 b i il. 17 b). Na poszczególnych nominałach zmieniają się głowy umieszczone w medalionach oraz wyrażona słownie i liczbowo wartość nominału. Na rewersie 5 marek polskich zostały umieszczone kobiece głowy w charakterystycznych hełmach (il. 16 b). Obecność tego atrybutu pozwala interpretować te wizerunki jako przedstawienie Ateny. W szacie graficznej banknotów emitowanych przez Polską Krajową Kasę Pożyczkową o nominałach - 2, 10 i 20 marek polskich umieszczone są identyczne głowy. Natomiast na przeznaczonej dla Generał-Gubernatorstwa Warszawskiego piędziesięciomarkówce wkomponowane zostały kobiece głowy zbliżone do popiersi przedstawiających Germanię na niemieckim banknocie o nominale 50 marek emisji 10 marca 1906 roku (por. il. 18 z il. 19 $)^{44}$. Na obydwu banknotach znalazły się portrety długowłosej kobiety z włosami spływającymi swobodnie na ramiona. Na jej skroniach umieszczone zostały wieńce $\mathrm{z}$ liści dębu. Zasadniczą różnicą $\mathrm{w}$ tych wizerunkach jest obecność stylizowanej Korony Cesarstwa Niemieckiego na głowie Germanii z banknotu o nominale 50 marek.

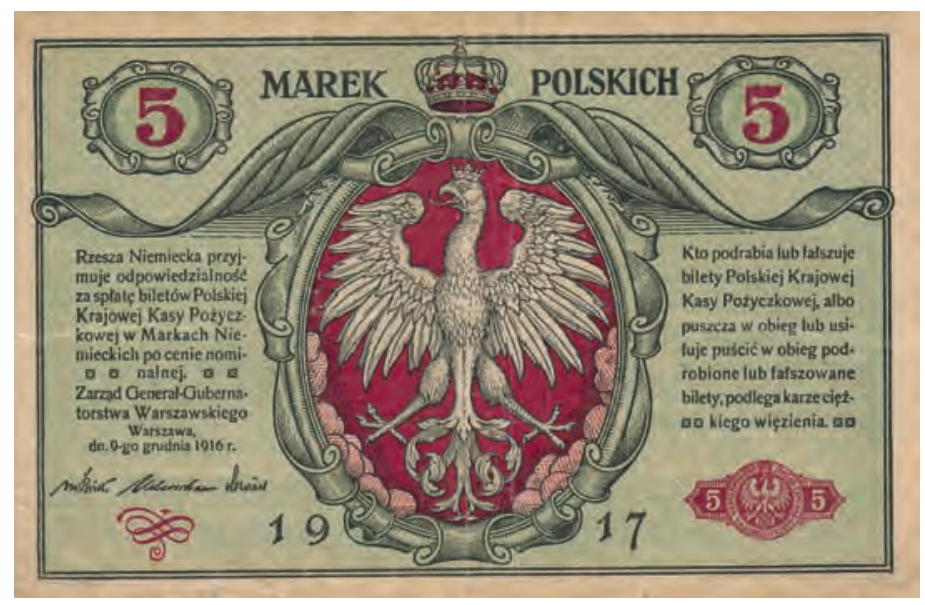

16 a. 5 marek polskich, 9 grudnia 1916 (awers)

${ }_{44}$ Nominał ten o niezmienionej szacie graficznej doczekał się jeszcze trzech emisji z datami emisji: 8 czerwca 1907, 7 lutego 1908 oraz 21 kwietnia 1910 roku. Standard Cata$\log \ldots$, s. 557-558. 


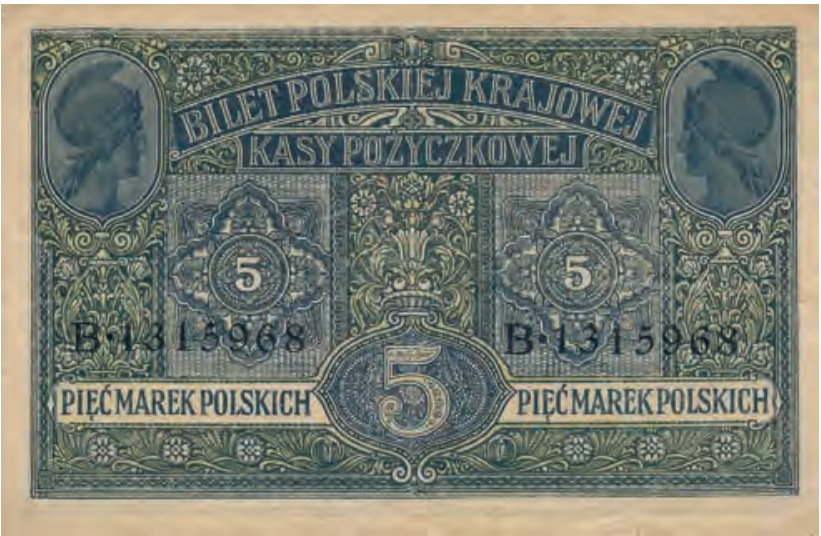

16 b. 5 marek polskich, 9 grudnia 1916 (rewers)

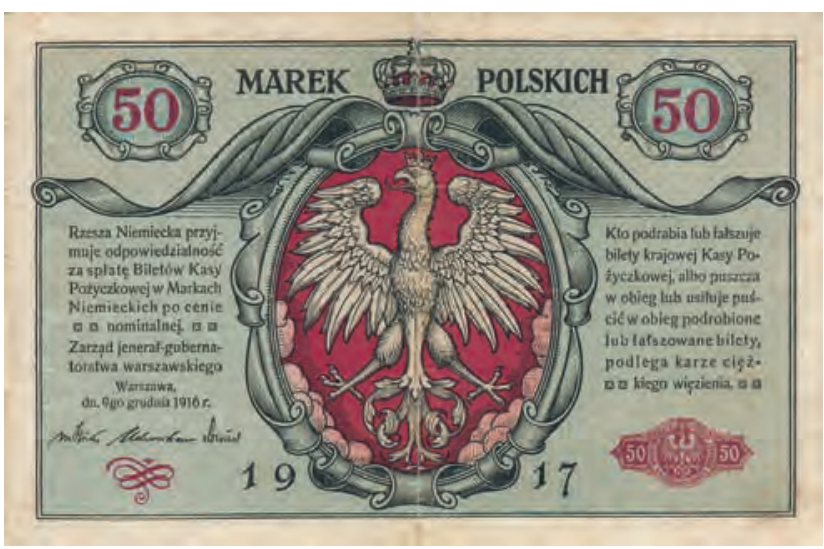

17 a. 50 marek polskich, 9 grudnia 1916 (awers)

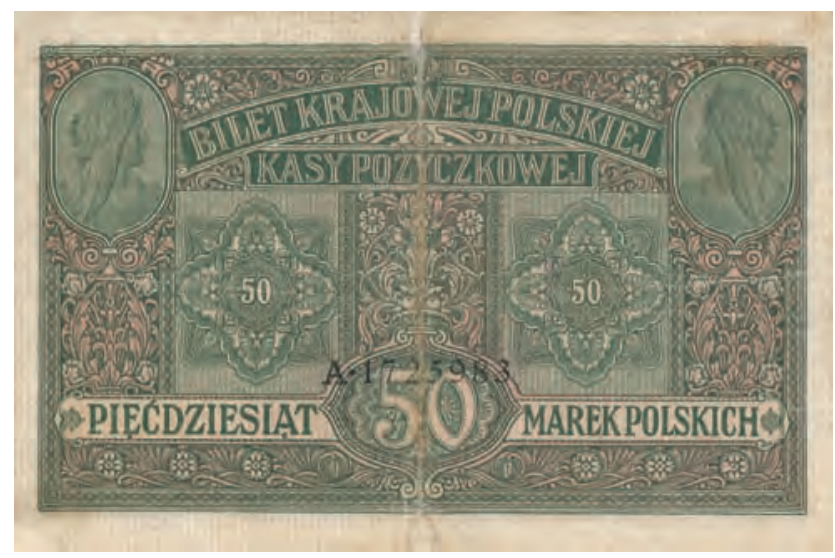

17 b. 50 marek polskich, 9 grudnia 1916 (rewers) 


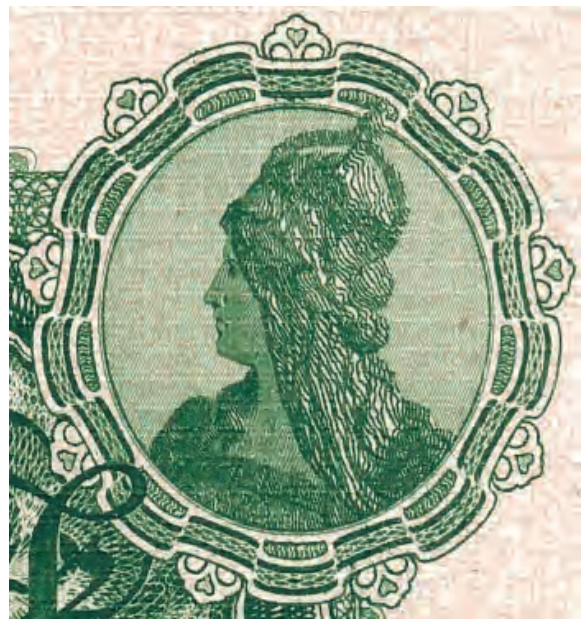

18. Detal z rewersu 50 marek, 10 marca 1906

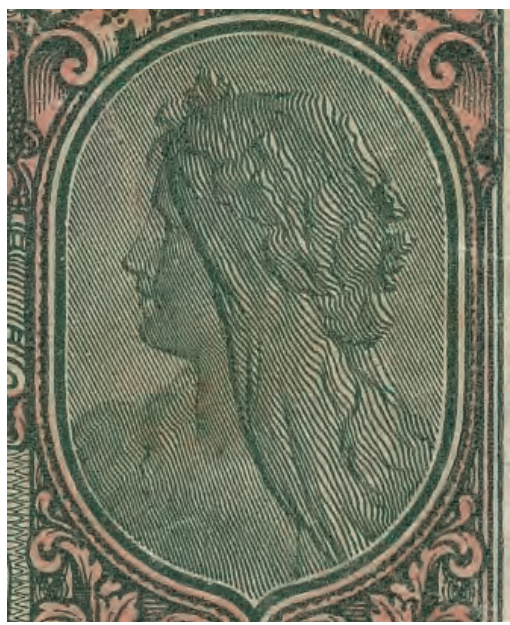

19. Detal z awersu 50 marek polskich, 9 grudnia 1916

Do ostatniej grupy należą dwa najwyższe nominały - 100 i 1000 marek polskich. Awersy tych pieniędzy papierowych zostały podzielone na trzy pola (il. 20 a i il. 25 a). W środkowej części zostały umieszczone informacje o nominale, a poniżej znalazła się czerwona winieta z pieczęcią Zarządu Generał-Gubernatorstwa Warszawskiego w otoczeniu dekoracji roślinnej. Wśród niej znalazły się dwa skierowane wylotami do dołu rogi obfitości. Z lewej strony awersu znajduje się stylizowany manierystyczny kartusz z wkomponowanym wewnątrz Orłem Białym na intensywnym czerwonym tle. Natomiast po przeciwnej stronie przedniej strony nominału w identycznym kartuszu, na czerwonym tle, została umieszczona wyrażona liczbowo wartość nominału. Na rewersach umieszczono symetrycznie dwa ośmiokątne pola ze zwróconymi ku sobie głowami (il. 20 b i il. 25 b). Na 100 markach polskich są to kobiece portrety w charakterystycznych hełmach, które można interpretować jako wizerunki Ateny. Natomiast na 1000 marek polskich umieszczono dwie różne głowy. W polu z lewej znalazło się popiersie Ateny w charakterystycznym hełmie oraz z włócznią. Projektujący banknot artysta, tworząc wizerunek bogini, najprawdopodobniej posiłkował się antyczną rzeźbą Atena Giustiniani (por. il. 20 b 
z il. 21$)^{45}$. Po przeciwnej stronie tylnej strony banknotu wkomponowane zostało ukazane $\mathrm{z}$ lewego profilu popiersie brodatego mężczyzny w czapce frygijskiej na głowie (il. 22). Tłem dla przedstawienia męskiej głowy jest koło zębate. Na lewym ramieniu mężczyzny można dostrzec fragment fartucha. Zespół atrybutów w postaci fartucha i koła zębatego pozwala interpretować popiersie brodatego mężczyzny jako wizerunek Hefajstosa - antycznego boga patrona rzemieślników. Jednak czapka frygijska na głowie mężczyzny nie występuje na wizerunkach bóstw starożytnej Grecji i Rzymu. Spotykana jest raczej u bóstw z Bliskiego Wschodu. Po rewolucji francuskiej czapka frygijska stała się symbolem wolności. W związku z tym przedstawienie to można interpretować jako personifikację przemysłu. Podobny męski portret został umieszczony na banknocie o nominale 1000 lei, który był w obiegu na okupowanych przez wojska państw centralnych terenach Królestwa Rumunii oraz na wyemitowanych w okresie hiperinflacji w Republice Weimarskiej nominale 500000 marek emisji 1 maja 1923 roku (por. il. 22 z il. 23 oraz il. 24). Na nominale 1000 marek polskich przedstawienie mężczyzny zostało rozbudowane o koło zębate oraz fartuch.

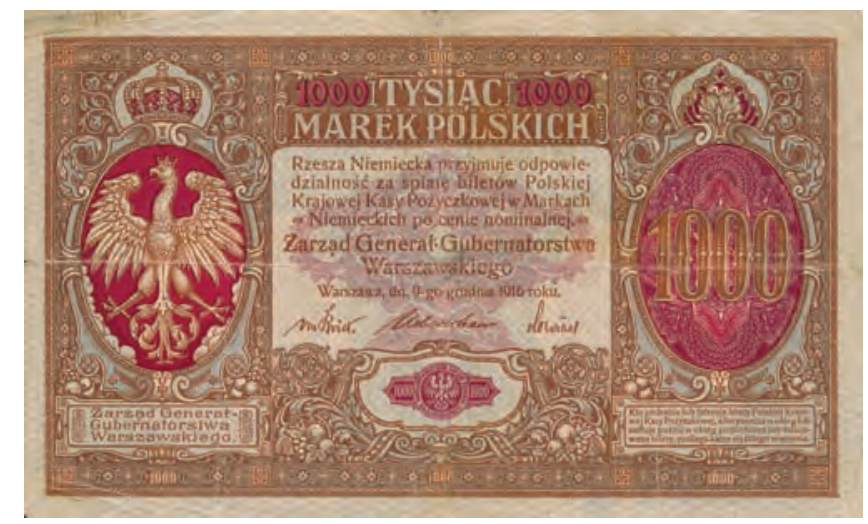

20 a. 1000 marek polskich, 9 grudnia 1916 (awers)

45 Przechowywana w Muzeach Watykańskich rzeźba jest rzymską kopią brązowej rzeźby greckiej datowanej na koniec V, początek IV wieku p.n.e. Atena Giustiniani została odkryta na początku XVII wieku. Jej nazwa pochodzi od nazwiska włoskiego kolekcjonera Vinceza Giustinianiego, w którego zbiorach się znalazła. Pierwsza wzmianka o niej znajduje się w katalogu kolekcji wydanym w 1631 roku. W 1805 roku kupił ją Lucjan Bonaparte, by w 1817 roku sprzedać ją papiezowi Piusowi VII, który umieścił ją w Muzeach Watykańskich. F. Haskell, N. Penny, Taste and the Antique. The Lure of Classical Sculpture 1500-1900, London 1982, s. 269-271. 


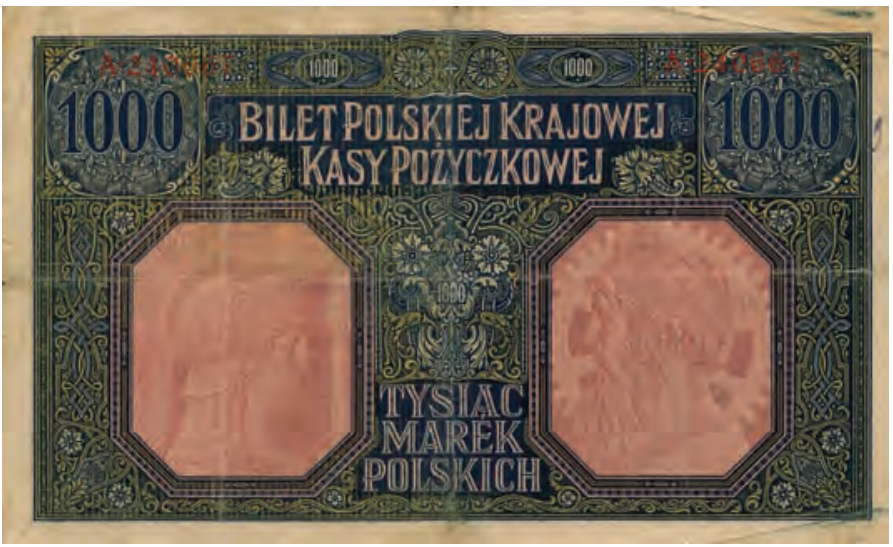

20 b. 1000 marek polskich, 9 grudnia 1916 (rewers)

21. Atena Giustiniani (rysunek)

Źródło: A. Springer, Powszechna ilustrowana historia sztuki, t. 1. Sztuka starożytna, przeł. K. Broniewski, Warszawa 1902, s. 188.

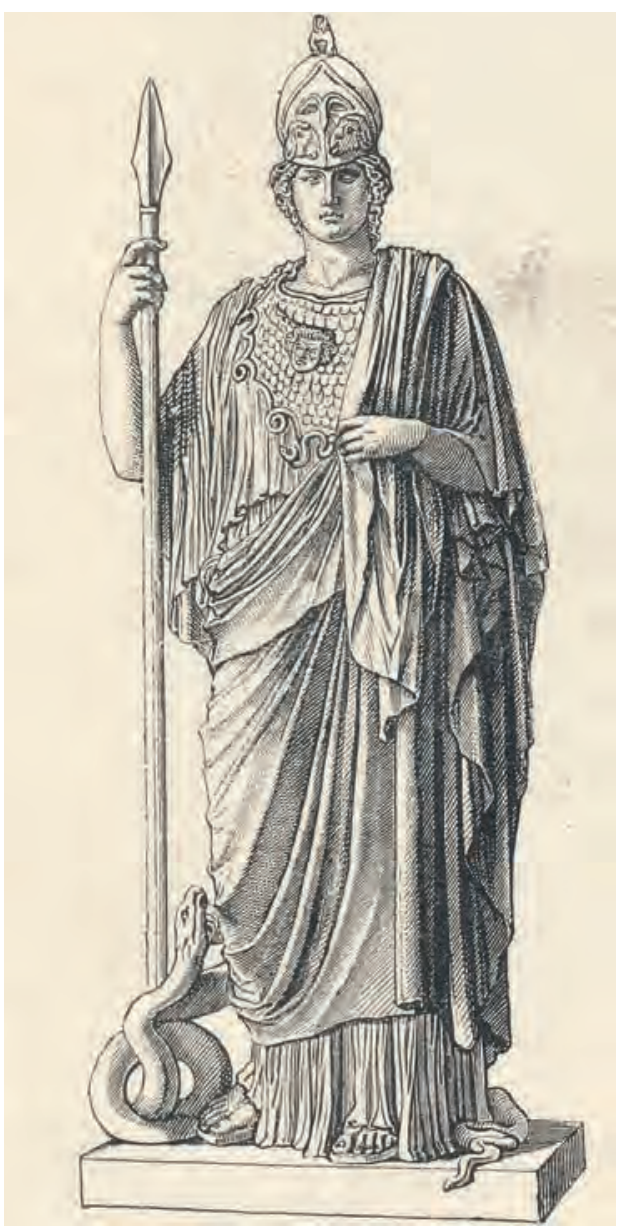



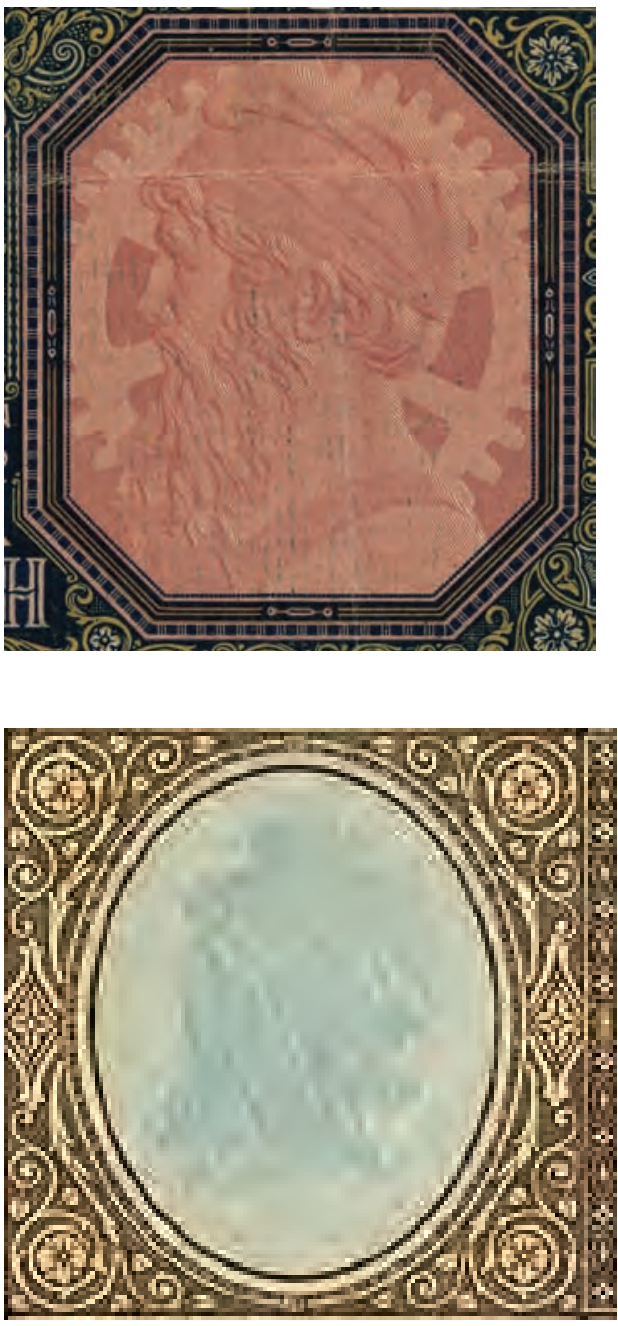

23. Detal rewersu 1000 lei [1917]
22. Detal rewersu 1000 marek polskich, 9 grudnia 1916

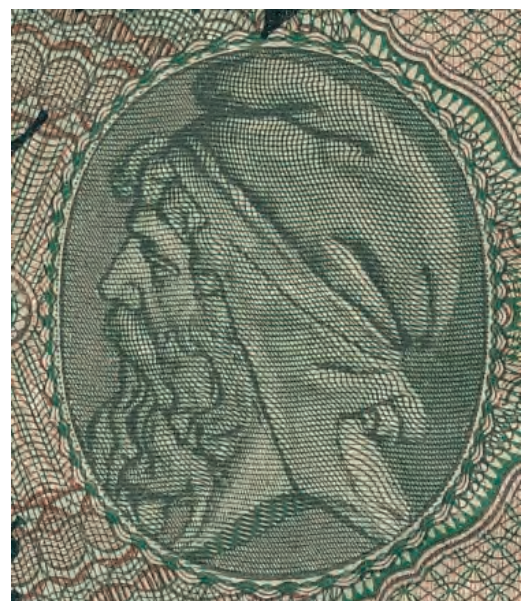

24. Detal awersu 500000 marek, 1 maja 1923

Odrodzone 11 listopada 1918 roku Rzeczpospolita Polska początkowo nie dysponowała nawet namiastką własnego skarbu, w związku z tym była zmuszona tolerować krążącą w obiegu wprowadzoną przez Niemców walutę. Do 1924 roku polską walutą pozostała marka polska, której kurs był powiązany z marką niemiecką ${ }^{46}$. Odziedziczone po Ge-

${ }^{46}$ R.M. Watt, Gorzka chwała. Polska i jej los 1918-1939, przeł. P. Amsterdamski, Warszawa 2005, s. 183; M. Markowski, op. cit., s. 111. 
nerał-Gubernatorstwie Warszawskim zapasy drukowanych w Berlinie marek polskich zostały w całości wprowadzone do obiegu. Brak dostatecznej ilości banknotów utrudniał zaspokajanie potrzeb Skarbu Państwa. Wobec niepowodzeń uzyskania w Berlinie znajdującego się tam zapasu banknotów oraz klisz, które pozwoliłyby na druk banknotów w kraju, dnia 31 grudnia 1918 roku dekretem Naczelnika Państwa upoważniono Polską Krajową Kasę Pożyczkową do druku banknotów wyłącznie o nominale 500 marek do kwoty 500 milionów marek polskich ${ }^{47}$. Żeby przyspieszyć proces tworzenia pieniędzy papierowych, pozostawiono szatę graficzną zaprojektowaną przez niemieckich projektantów dla banknotu o nominale 100 marek polskich (por. il. 30 a z il. 31 a oraz il. $30 \mathrm{~b}$ z il. $31 \mathrm{~b}$ ). Wprowadzony do obiegu podczas pierwszej wojny światowej banknot o nominale 100 marek polskich posłużył jako pierwowzór dla pierwszego w odrodzonym państwie polskim banknotu o nominale 500 marek polskich emisji 15 stycznia 1919 roku. Tworząc ten nominał, pozostawiono szatę graficzna, lecz zmieniono wartość nominalna, podpisy oraz klauzulę prawna, w której to Państwo Polskie, a nie Rzesza Niemiecka, zobowiązywało się do jego wymiany na przyszłą polską walutę. Zmianie uległ również znak wodny ${ }^{48}$.

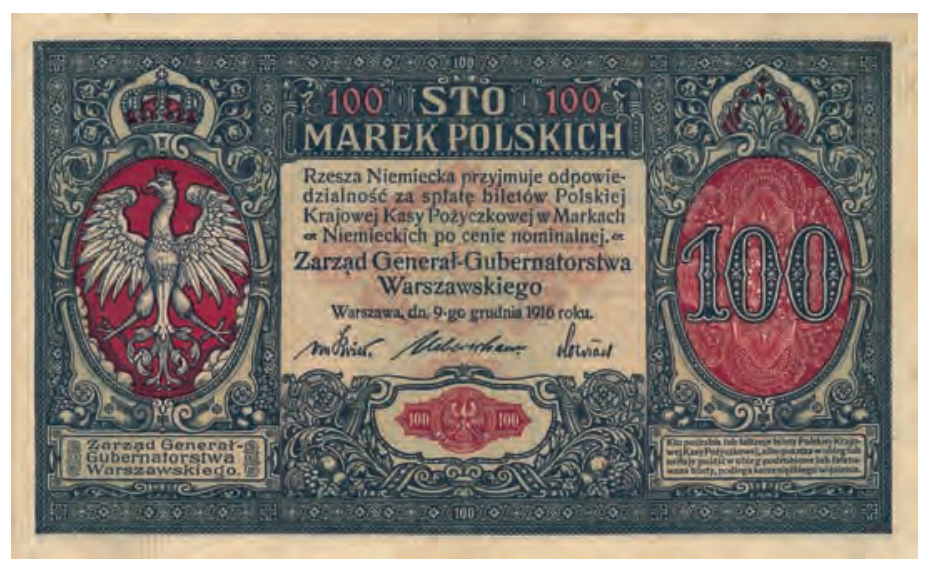

25 a. 100 marek polskich, 9 grudnia 1916 (awers)

47 Z. Karpiński, Ustroje pieniężne w Polsce od roku 1917, Warszawa 1968, s. 30-32; M. Markowski, op. cit., s. 112.

48 Ibidem. 


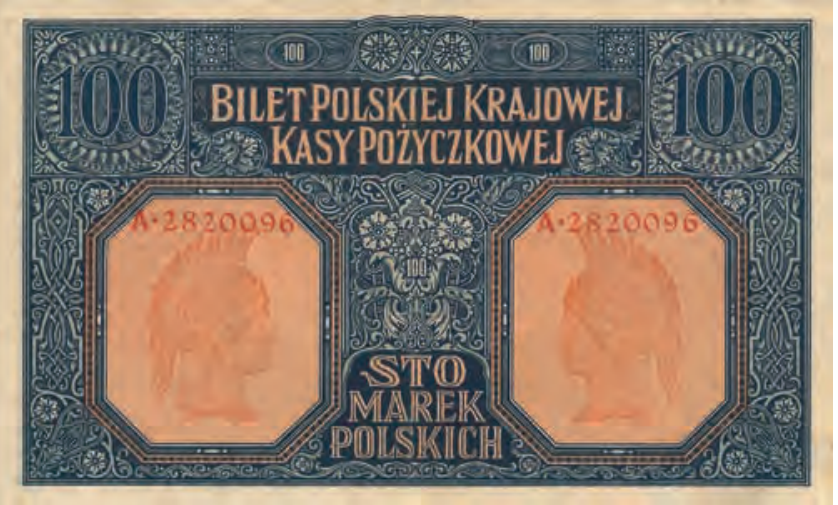

25 b. 100 marek polskich, 9 grudnia 1916 (rewers)

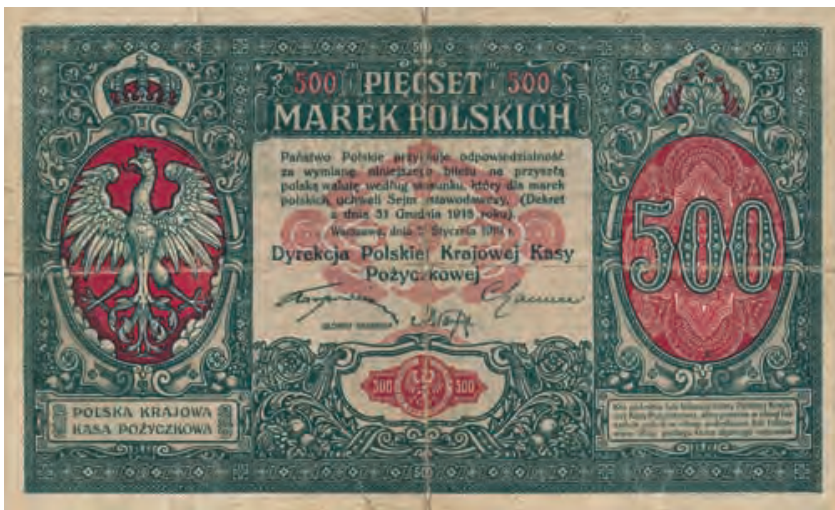

26 a. 500 marek polskich, 15 stycznia 1919 (awers)

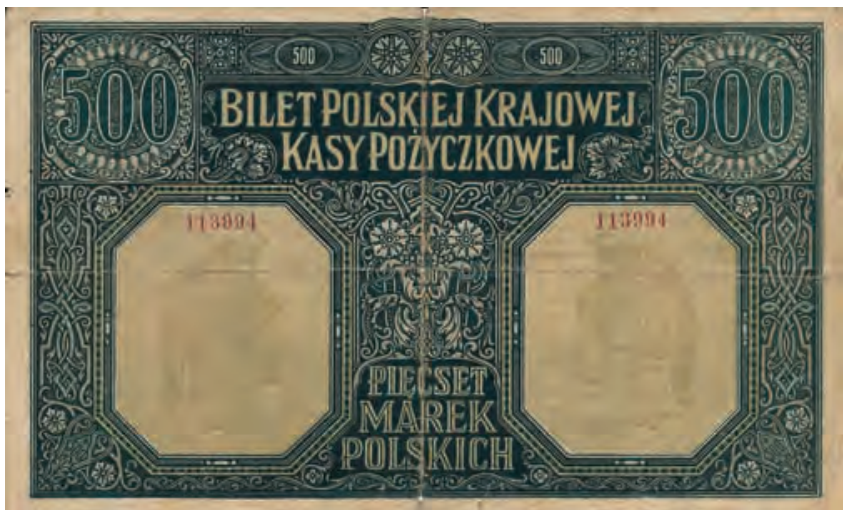

26 b. 500 marek polskich, 15 stycznia 1919 (rewers) 
Na zajętych przez wojska niemieckie w czasie pierwszej wojny światowej terenach Imperium Rosyjskiego oraz Królestwa Rumunii władze okupacyjne utworzyły nowe instytucje emisyjne, które emitowały własne środki płatnicze. Wprowadzanie do obiegu nowych, pod względem szaty graficznej, pieniędzy papierowych rozpoczęło się w połowie 1916 roku. Po zakończeniu działań wojennych utworzone przez Niemców instytucje: Wschodnia Kasa Pożyczkowa i Polska Krajowa Kasa Pożyczkowa pełniły funkcję banków centralnych Litwy i Polski w pierwszych latach po odzyskaniu niepodległości.

Spośród pieniędzy emitowanych przez Niemców na terenach okupowanych na Wschodzie najbardziej ubogą szatę graficzną miały niższe nominały rubli i marek wschodnich przeznaczonych dla terenów Ober-Ostu, gdzie znalazł się jedynie rysunek ornamentalny. Natomiast najwyższe nominały - 100 ostrubli oraz 100 i 1000 ostmarek mają bardzo rozbudowaną ikonografię, która wyróżnia je spośród pieniędzy papierowych przeznaczonych dla okupowanych przez Niemców terenów na wschodzie Europy. Najbardziej narodowy charakter miały banknoty przeznaczone dla Generał-Gubernatorstwa Warszawskiego, który nadawała im obecność Orła Białego na intensywnym czerwonym tle. Natomiast pieniądze papierowe przeznaczone dla pozostałych okupowanych przez wojska niemieckie terytoriów, oprócz języka, nie miały cech graficznych które byłyby skierowane do grup narodowościowych, takich jak Litwini, Łotysze czy Rumuni. Wszystkie pieniądze papierowe emitowane na terenach okupowanych przez wojska niemieckie podczas pierwszej wojny światowej były zabezpieczone bieżącym znakiem wodnym. W szacie graficznej tych banknotów znajdziemy również odwołania do mitologii Greków i Rzymian. Nawiązania te są czytelne za pośrednictwem kobiecych i męskich popiersi, które poprzez zespół charakterystycznych atrybutów można interpretować jako wizerunki Demeter, Ateny, Hermesa czy Aresa. Przedstawienia bóstw w szacie graficznej pieniędzy papierowych $\mathrm{z}$ tego rejonu świata nie są ewenementem. Znajdziemy je bez problemu na banknotach emitowanych w innych państwach począwszy od końca XIX do lat pięćdziesiątych i sześćdziesiątych XX wieku. Jednak największa ilość takich przedstawień umieszczana była w szacie graficznej pieniędzy papierowych emitowanych na świecie w pierwszej połowie $X X$ wieku. 


\section{Abstract \\ The Graphic Design of Paper Money Issued in the Territories Occupied by the German Army During World War I}

The occupation authorities set up their own institutions that issued their own legal tender banknotes in the territories of the Russian Empire and the Kingdom of Romania occupied by the German army during World War I. The introduction of paper money with a new graphic design began in the middle of 1916.

Lower denominations of ostrubles and ostmarks, designed for areas east of the Ober-Ost, had the poorest layout of all the money issued by the Germans in the occupied territories in the East - they were embellished only by an ornamental drawing. In contrast, the highest denominations - 100 ostrubles, 100 and 1,000 ostmarks - had a very extensive iconography, which distinguished them from paper money earmarked for the occupied territories in Eastern Europe. Banknotes intended for the General Government of Warsaw had the most national character due to the presence of the White Eagle on the intense red background. In contrast, apart from the language, paper money intended for other occupied territories did not have any graphic features that would be targeted at ethnic groups such as the Lithuanians, Latvians and Romanians. The layouts of these banknotes contain references also to the Greek and Roman mythologies. These references include male and female busts and a group of characteristic attributes that suggest that these are images of Demeter, Athena, Hermes and Ares. 